DEMOGRAPHIC RESEARCH

VOLUME 38, ARTICLE 38, PAGES 1111-1154

PUBLISHED 22 MARCH 2018

http://www.demographic-research.org/Volumes/Vol38/38/

DOI: 10.4054/DemRes.2018.38.38

Research Article

The formation of ethnically mixed partnerships in Estonia: A stalling trend from a two-sided perspective

Allan Puur

Leen Rahnu

\section{Luule Sakkeus}

Martin Klesment

\author{
Liili Abuladze
}

This publication is part of the Special Collection "A New Look Into the Dynamics of Mixed Couples in Europe," organized by Guest Editors Amparo González-Ferrer, Laura Bernardi \& Alícia Adserà.

(C) 2018 Allan Puur et al.

This open-access work is published under the terms of the Creative Commons Attribution 3.0 Germany (CC BY 3.0 DE), which permits use, reproduction, and distribution in any medium, provided the original author(s) and source are given credit.

See https://creativecommons.org/licenses/by/3.0/de/legalcode. 


\section{Contents}

1 Introduction 1112

2 Theoretical perspectives and previous findings on mixed 1114 partnerships

3 The context 1117

3.1 Ethnic majority and minority groups 1117

3.2 Evidence pertaining to ethnically mixed partnerships in Estonia 1118

$4 \quad$ Research aim and hypotheses 1120

$5 \quad$ Data and analytical approach $\quad 1122$

6 Results 1124

6.1 Formation of partnerships among the minority population 1124

6.2 Partnership formation among the majority population 1128

$7 \quad$ Summary and discussion of the findings 1132

$8 \quad$ Acknowledgements 1137

$\begin{array}{ll}\text { References } & 1138\end{array}$

$\begin{array}{ll}\text { Appendix } & 1148\end{array}$ 


\title{
The formation of ethnically mixed partnerships in Estonia: A stalling trend from a two-sided perspective
}

\author{
Allan Puur ${ }^{1}$ \\ Leen Rahnu ${ }^{2}$ \\ Luule Sakkeus ${ }^{1}$ \\ Martin Klesment ${ }^{1}$ \\ Liili Abuladze ${ }^{1}$
}

\begin{abstract}
BACKGROUND

Ethnically mixed partnerships are often regarded as the ultimate evidence of the integration of migrants and their descendants into their host society. A common finding in the literature is an increase in the occurrence of mixed partnerships across migrant generations.
\end{abstract}

\section{OBJECTIVE}

This study investigates the formation of minority-majority partnerships in Estonia, with special attention to the variation associated with the migrants' generation and their exposure to the majority population.

\section{METHODS}

The study uses pooled data from the Estonian Family and Fertility Survey (FFS) and the Estonian Generations and Gender Survey (GGS), and estimates proportional hazards models.

\section{RESULTS}

The experience of second-generation migrants indicates a stalling trend in the incidence of mixed partnerships between the majority population and migrant groups, which is rooted in contextual features. Apart from residential proximity, the study shows the salience of early acquisition of the host society language. Our results for the majority population highlight the role of international migration, which exposes host populations to mixed partnership formation.

\footnotetext{
${ }^{1}$ Estonian Institute for Population Studies, Tallinn University, Estonia.

${ }^{2}$ Estonian Institute for Population Studies, Tallinn University, Estonia. Email: leen.rahnu@tlu.ee.
} 


\section{CONCLUSIONS}

The results lend support to the view that the integration of migrant populations through mixed partnering is a lengthy process that stretches across several generations. A linguistically divided school system and residential segregation contribute to the pillarization of society.

\section{CONTRIBUTION}

By focussing on an Eastern European context, the study contributes to a more comprehensive account of mixed unions in different socioeconomic and cultural settings. Estonia provides an interesting case as its migrant-origin minorities span several generations. The study underscores the importance of contextual factors for both the minority and majority populations.

\section{Introduction}

In the literature the incidence of ethnically mixed partnerships between migrants and the native population is considered both an important measure of integration and a factor that promotes it (Gordon 1964; Hwang, Saenz, and Aquirre 1997; Alba and Nee 2003; Holloway et al. 2005; Fu 2006). From a social cohesion perspective, mixed partnerships connect not only individuals who are directly involved but also the groups to which these individuals belong. Research on partner selection has demonstrated that people usually prefer to choose a partner from their own group, or someone who is similar to themselves in terms of social and cultural characteristics (Kalmijn 1998). In this context partnering between immigrants and natives is seen as a marker of advanced integration that tends to occur only after immigrants and their descendants have undergone successful structural and cultural integration into the host society (Kalmijn and van Tubergen 2010).

The formation of ethnically mixed unions depends on a variety of factors that relate to structural opportunities to meet potential partners from outside one's own group, individual preferences for a partner with certain characteristics, and the influence of individuals who are directly involved in the partnership - so-called third parties (Kalmijn 1998; Kulu and Gonzáles-Ferrer 2014). In this study we analyse the formation of ethnically mixed partnerships between ethnic minorities of mainly immigrant background and the native majority population. ${ }^{3}$ It is generally expected that there

\footnotetext{
${ }^{3}$ Minority-minority partnerships can also be ethnically mixed. Studying exogamous minority-minority partnerships may be interesting in its own right (Kao and Joyner 2006; Çelikaksoy 2012) but is beyond the scope of this analysis.
} 
would be an increase in interethnic partnering when moving from first-generation migrants to their descendants (Lieberson and Waters 1988; Logan and Shin 2012). Our aim is to gain insight into the factors that facilitate a change in the likelihood of forming interethnic partnerships across migrant generations, including the characteristics of parents, language proficiency, opportunities for interethnic encounters, and educational attainment. The empirical evidence of the study comes from pooled data from the Estonian Family and Fertility Survey and the Estonian Generations and Gender Survey. Proportional hazards models are used to investigate the formation of mixed partnerships.

Our study contributes to the literature in three ways. First and foremost, we add to previous research by focussing on the factors that are responsible for the increase in interethnic partnerships from one generation to the next. Studies on intermarriage have shown considerable variation in the incidence of ethnically mixed unions as well as in the role of factors shaping this process (Lanzieri 2012; Hannemann et al. 2016; van Ham and Tammaru 2016). European research on mixed partnerships has focussed predominantly on western countries, with relatively few studies available on the eastern part of the continent (Botev 2002; Monden and Smits 2005; van Ham and Tammaru 2011). By investigating the Estonian context, our study contributes to a more comprehensive account of the issue in different socioeconomic and cultural settings. Estonia offers a particularly interesting case for studying ethnically mixed partnerships because the early onset of post-war immigration has resulted in a foreign-origin population that spans several migrant generations. This enables us to study the descendants of immigrants and to obtain results that can be compared with findings pertaining to the second generation in Northern and Western Europe.

Second, research on interethnic partnerships often tells the story only from the perspective of the immigrants (Coleman 1994; Dribe and Lundh 2008, 2011; Chiswick and Houseworth 2011). This study contributes to the literature by employing a twosided approach and examining the formation of interethnic unions from the point of view of both immigrants and natives. We also investigate the patterns separately for women and men, which permits us to explore gender patterns in mixed partnerships.

Third, while much of the empirical research on ethnic intermarriage draws its evidence from cross-sectional data (Kalmijn and van Tubergen 2006, 2010; van Ham and Tammaru 2011), we contribute to the literature by using longitudinal data. This allows us to account for the fact that many factors influencing the formation of interethnic partnerships can vary over time. Therefore, the temporal ordering of life events is essential for a more precise examination of their effects.

Structurally the article comprises seven sections. In the next section we briefly discuss the theoretical approaches to the formation of interethnic partnerships and the main empirical findings to date. We then present some background information on 
Estonia, which, along with the theoretical perspectives, provides a basis for our hypotheses. The following sections describe the data and methods employed in the study, as well as the empirical results pertaining to the formation of interethnic and coethnic partnerships. The final section provides a summary and discussion of the main findings.

\section{Theoretical perspectives and previous findings on mixed partner- ships}

Research on marriage and partnering indicates that people generally choose partners who are similar to themselves (positive assortative mating) in terms of demographic, socioeconomic, and cultural characteristics (Kalmijn 1998; Kalmijn and van Tubergen 2006). As a consequence, endogamous unions are the most common, which suggests that such unions best meet the expectations and needs of the partners involved.

Immigrants and ethnic minorities frequently exhibit features that distinguish them from the native majority within the host society. These features, ranging from visible appearance to cultural values and beliefs, are viewed as major factors that hinder the formation of ethnically mixed minority-majority partnerships. However, most of these features are not static but subject to change over time. Assimilation theory has long been the most influential approach to describing the paths which lead to the integration of immigrants into the host society. It has been successfully applied to integration and trends in intermarriage among ethnic groups of European origin in the United States (Alba and Golden 1986; Lieberson and Waters 1988; Alba and Nee 2003; Spörlein, Schlueter, and van Tubergen 2013). The process of integration comprises acculturation (learning the host country language or adopting its cultural patterns) and structural integration (achieving parity with the native majority in socioeconomic status). According to classical assimilation theory, complete integration is achieved when there are no perceived differences between the immigrant or minority group and the native population of the host country (Gordon 1964). Integration weakens ethnic attachment and increases contact with potential partners from other groups, which further increases the propensity for exogamy. In this context interethnic partnerships are seen both as an element and a logical outcome of the integration process (Lieberson and Waters 1988).

According to the assimilation perspective, the members of an ethnic minority population who have been in the host country longer, or who, by virtue of belonging to the second (or a later) generation, have grown up in the host society, will be more likely to form partnerships with the native majority. Indeed, most studies concerning interethnic partnerships find that second-generation migrants are more likely to partner with natives than their first-generation peers (van Niekerk 2007; Muttarak and Heath 
2010; Safi 2010). This is hardly surprising, given the cultural and language barriers that many immigrants encounter upon arrival. Their opportunities to interact with people outside their own group are further reduced if their educational and labour market experience is restricted. However, recent evidence suggests that in a number of European countries partnership patterns of the descendants of immigrants have proven to be more complex, with intragroup unions being more common than previously expected. This is due in some measure to the practice of bringing coethnic partners from their parents' countries of origin (González-Ferrer 2006; Milewski and Hamel 2010; Hartung et al. 2011; Huschek, de Valk, and Liefbroer 2012). Research on the descendants of immigrants has also revealed that even in the same destination country different migrant and minority groups can exhibit substantial variation in the rates of partnering with the native majority (Dribe and Lundh 2011; Spörlein, Schlueter, and van Tubergen 2013).

The integration of immigrants is also considered in the framework of the segmented assimilation theory (Portes and Zhou 1993; Portes, Fernández-Kelly, and Haller 2005). With reference to the United States, the proponents of this theory distinguished several pathways of integration into the host society. As alternatives to assimilation into the white middle class, they posited assimilation into the urban underclass, leading to downward mobility and the deliberate preservation of the ethnic group's identity and culture, combined with successful structural integration (Zhou 1997; Haller, Portes, and Lynch 2011). Although these specific pathways are not directly transferable to European countries (Crul and Schneider 2010; Vermeulen 2010), the idea of multiple paths to integration has attracted some interest in European studies of ethnic intermarriage (Peach 2005; Muttarak and Heath 2010; Song 2010). From a related perspective, previous research has demonstrated the salience of cultural similarity (in terms of values, language, and religion) of migrants to the host society, which increases the rate of partnering with the native majority (Hurtado 1995; Lucassen and Laarman 2009; Dribe and Lundh 2011). On the individual level, intermarriage with a native in the parental generation is reported to significantly enhance the chances that a second-generation (or later) migrant will cross cultural barriers and enter a minoritymajority union (Monden and Smits 2005; Çelikaksoy 2012; Logan and Shin 2012).

Education is another factor that has been found to increase the rate of interethnic partnership formation (Alba and Golden 1986; Kalmijn 1993; Qian 1997; Kulczyki and Lobo 2002; Fu and Heaton 2008; Hartung et al. 2011; Huschek, de Valk, and Liefbroer 2012), although some studies have not exhibited this effect (Hwang, Saenz, and Aguirre 1997; Qian, Blair, and Ruf 2001; Gullickson 2006). According to Kalmijn (2012), the mechanisms underlying the hypothesised positive educational gradient in intermarriage relate to both the cultural and structural perspectives. The cultural explanation relates to people's views and attitudes with regard to various ethnic groups. Overall, high 
educational attainment is associated with more openness toward different cultures, which leads more highly educated individuals to more readily accept an exogamous partner (Quillian 1995; Wagner and Zick 2006; Tolsma 2009). According to the structural perspective, advanced education increases the opportunities to interact with out-group members, which may be conducive to interethnic partnerships.

A popular approach to explaining both exogamy and endogamy is social exchange theory, as laid out by Merton (1941) and Davis (1941). The social exchange perspective conceptualises union formation as a transaction process in which partners assess the resources and attributes they bring into the union, with each seeking to maximise his or her gains in the process. Since individuals with equivalent resources are most likely to maximise the rewards, most unions tend to be homogamous with respect to partners' characteristics (Schoen 1986). If the characteristics are not similar between potential partners, equivalence can be reached by trading different resources. For instance, an older individual with great wealth may seek to maximise his or her gains in an exchange with someone younger who has fewer resources, thus correcting the imbalance (Becker 1981). With regard to interethnic unions, exchange theory posits that majority partners must be compensated for their position as members of the dominant group. To ensure equivalence, minority partners are expected to have superior characteristics, such as greater attractiveness or better education, relative to their peers who partner endogamously. Conversely, majority partners who accept minority mates are thought to be selected for characteristics inferior to their counterparts who partner within their group. These predictions have been supported by studies of marriage between black men and white women in the United States (Schoen and Wooldredge 1989; Kalmijn 1993; Bankston and Henry 1999; Qian and Lichter 2001) and interracial marriages in Brazil (Gullickson and Torche 2014). However, limited or no support for these predictions was found in studies of mixed marriages between whites and Asians (Schoen and Thomas 1989; Fu 2006, 2008; Liang and Ito 2008).

Finally, structural characteristics of the partner market are important determinants of individual choice (Blau and Schwartz 1984; Kalmijn and van Tubergen 2010; Niedomysl, Östh, and van Ham 2010). According to the opportunity structure perspective, the possibilities for inter-group endogamy depend on the group size and sex ratios among ethnic minorities. Similarly, geographical concentration and segregation in other domains of society (educational system, labour market) play an important role (van Ham and Tammaru 2016). Related to interethnic contact, proficiency in the host country language is frequently identified as a prominent factor that facilitates the formation of minority-majority partnerships (Stevens and Swicegood 1987; Hwang, Saenz, and Aguirre 1997; Furtado and Theodoropoulos 2001; Kulczycki and Lobo 2002; Huijnk, Verkuyiten, and Coenders 2010). 


\section{The context}

\subsection{Ethnic majority and minority groups}

Large-scale immigration to Estonia started in 1945, following the country's incorporation into the Soviet Union during the Second World War, and remained high until the late 1980s (Sakkeus 1994). Persistent immigration entailed a major transformation in the composition of the population. The proportion of the ethnic (Estonian) majority decreased from an estimated $97 \%$ in 1945 to $62 \%$ at the last Soviet enumeration (1989), while the share of ethnic minority groups more than decoupled over the same period to reach $38 \%$.

The restoration of Estonia's independence in 1991 halted large-scale immigration and triggered a wave of return migration (Tammaru and Kulu 2003). At the turn of the $21^{\text {st }}$ century ethnic minority groups constituted $32 \%$ of the total population of Estonia. During the 2000s, their share decreased even further, driven by negative net migration and an excess of deaths over births; in 2016 ethnic minority groups constituted $31 \%$ of the total population. Unlike in the prewar period, the contemporary minority population in Estonia is of predominantly migrant origin. According to the latest census, firstgeneration migrants comprise two-fifths of the population, and the second and subsequent generations comprise three-fifths. ${ }^{4}$ This contextual feature enables a migrant-generation perspective to be applied to the study of interethnic unions. The ethnic origins of the minority groups reflects the geography of Soviet-era migration to Estonia. In 2011 three Slavic groups accounted for an overwhelming 92\% of the minority population (Russians $83 \%$, Ukrainians $6 \%$, and Byelorussians $3 \%$ ). ${ }^{5}$

Another interesting feature of the Estonian context is the fact that a considerable proportion of the ethnic majority population also has a migrant background. Following the onset of the demographic transition in the middle of the $19^{\text {th }}$ century, Estonia experienced out-migration, mainly directed to other areas of the Russian Empire. The migration of Estonians to Russia was followed by significant return flows, which occurred in the early 1920s after the establishment of the Estonian Republic, and again in the 1940s and 1950s following the annexation of Estonia into the Soviet Union (Kulu 1997, 2000). Political repression and deportations during the 1940s and early 1950s added yet another layer to the migration history of the majority population. This migration experience is common to a substantial proportion of the majority covered in this study. Characteristics such as foreign-born parents, birth and socialisation in

\footnotetext{
${ }^{4}$ Note that the census figures comprise all age groups. The surveys on which this case study draws cover adult age groups, which contain a higher proportion of first-generation migrants and a lower proportion of their descendants.

${ }^{5}$ The origins of the post-1990 arrivals are more diverse. In the intercensal period, 2000-2011, the proportion of Russians among the enumerated new arrivals had decreased to $37 \%$ (ESA 2017).
} 
another country, or residence abroad for several years may affect the propensity to enter into a mixed partnership, and merits attention in this study.

A distinguishing feature of the ethnic minority population in Estonia has been its relatively slow and uneven integration into the host society. This is most clearly visible in the level of skill in the host country language, which, to a large extent, constitutes a legacy of the period when Estonia was under Soviet rule. ${ }^{6}$ As a consequence a mere $15 \%$ of the minority population residing in the country could speak Estonian in the late 1980s. Language proficiency has subsequently improved, reflecting a deliberate process of nation building (Koreinik and Tender 2013; Puur, Rahnu, and Valge 2016). The 2011 census reported that $43 \%$ of the ethnic minority population could speak the host country language; language proficiency appears highest (about $70 \%$ ) among the young adults.

Integration is hindered by a very high concentration of ethnic minorities in certain areas of the country (Tammaru and Kontuly 2011). At the time of the last census, ethnic minorities comprised $45 \%$ of the population of the capital city and $88 \%$ of the northeastern industrial towns. In contrast, minorities constituted $9 \%$ of the rural population on average, with an even lower percentage in most areas. Another potent factor that maintains segregation between the majority and minority population is the linguistic divide in the educational system (Rannut 2008). During the Soviet period there were separate schools with Estonian or Russian as the language of instruction: the latter followed the curriculum developed for schools in the Russian Federation. Although extensive changes have been introduced into the Estonian education system since 1991, the division of general education by language of instruction still persists, restricting contacts between minority and majority youth. Finally, labour market studies have revealed considerable differences in the structure of the minority and majority workforce in Estonia (Puur 2000; Pavelson and Luuk 2002). Following the transition to a market economy, minorities have experienced greater difficulty adapting to the new labour market reality, not least due to limited proficiency in the host country language (Luuk 2009; Lindemann 2013). Minority workers tend to be overrepresented in manual labour jobs, which closely resembles the pattern observed in the countries of Western Europe (Heath and Cheung 2007; Rendall et al. 2010).

\subsection{Evidence pertaining to ethnically mixed partnerships in Estonia}

In Estonia statistical evidence concerning the spread of interethnic partnerships is relatively limited for the post-war decades. Although data on the ethnicity of brides and grooms was collected as part of the former Soviet Union's vital statistics registration

\footnotetext{
${ }^{6}$ In the former Soviet Union, Russian was promoted as the main language of interethnic communication.
} 
system, cross-tabulations of marriages by ethnicity of the spouses were produced only for some years; moreover, the tabulations were for official use and never published (Botev 2002; Katus and Puur 2003). Data from sample surveys was also scarce. Although some studies were based on survey data, the samples were too small to draw detailed conclusions (Roosson 1984). The most comprehensive estimates concerning ethnic intermarriage are those based on census returns. Volkov (1989) reported that between the 1959 and 1979 censuses, the proportion of ethnically mixed couples increased from $10 \%$ to $16 \%$ in Estonia. According to Volkov's account, among ethnic Estonians, majority-minority couples constituted $13 \%$ of all married and cohabiting couples as of the late 1970s. Reflecting the impact of large-scale in-migration, these figures markedly exceed the levels reported for prewar Estonia. ${ }^{7}$ For the period following the restoration of Estonia's independence, the evidence derived from birth statistics suggests that the incidence of mixed unions has neither increased nor decreased significantly; on average, $6 \%$ of children born to majority mothers from 1990 to 2016 have had a minority father. ${ }^{8}$

In more recent research, van Ham and Tammaru (2011) analysed the formation of minority-majority unions using data from the 2000 census. In accord with the assimilation perspective, they found that mixed ethnic partnerships were more common among second- and third-generation immigrants as compared with the first generation. Members of the largest groups (Russians, Ukrainians, and Byelorussians) were found to be the least likely to form partnerships with the majority population, while Finns, who are culturally close to Estonians, appeared to be the most likely to form interethnic partnerships with the native majority. The rate of mixed union formation was highest among members of the minority population who resided in rural areas with the greatest exposure to the native majority. Contrary to expectations derived from the social exchange theory, highly educated members of the ethnic minority population seemed to prefer coethnic rather than majority partners.

Despite some interesting results, previous research pertaining to mixed partnerships in Estonia has some serious limitations. Most importantly, the analysis of partnership formation was constrained by the cross-sectional nature of the data. Combined with a limited choice of explanatory variables available from the census, the cross-sectional approach prevented further elaboration of the observed relationships. This study aims to advance the aforementioned research by taking advantage of a life history dataset that covers both the majority and minority populations in Estonia.

\footnotetext{
${ }^{7}$ From 1932 to 1934 the proportion of ethnically mixed marriages was less than 3\% in Estonia (Roosson 1984).

${ }^{8}$ The account is based on registered births for which information was available on both parents. Births to single mothers were not considered.
} 


\section{Research aim and hypotheses}

The aim of this study is to investigate the formation of mixed partnerships between the ethnic minority and majority populations from a generational perspective. We seek to provide insight into the factors that facilitate a change in the likelihood of interethnic partnerships across migrant generations, including the characteristics of parents, language proficiency, opportunities for interethnic encounters, and educational attainment. A review of theoretical considerations, previous empirical findings, and their context leads us to make the following hypotheses.

Our first hypothesis (H1) is that the likelihood of forming ethnically mixed partnerships increases across migrant generations. This assertion draws mainly on the socialisation argument embedded in the assimilation perspective. As the second- and particularly the third-generation members of minority groups develop closer ties to the host society, it is assumed that they would partner with the majority population at a higher rate than the first generation. However, considering the relatively slow integration of ethnic minorities in Estonia discussed above, and the contextual factors that have hindered the process, it is also possible that we would find a relatively small difference in the rate of endogamy between migrants and their descendants.

In order to gain insight into the mechanisms that drive the plausible intergenerational change in the occurrence of mixed partnerships, we take advantage of evidence that pertains to the parental home and formative years. Our second hypothesis (H2) posits that the characteristics of the parental family can substantially increase the probability of initiating an interethnic union. In accord with the socialisation perspective, we assume that having mixed minority-majority parentage may be particularly influential, as it entails the most intimate familiarity with the culture and values prevailing in the host society. In testing our second hypothesis, we pay additional attention to early exposure to the host country's language in the parental home or at school, which is assumed to significantly facilitate the formation of mixed unions. Conversely, a poor or nonexistent command of the host country's language is expected to markedly reduce the chances of partnering with majority women or men.

Our third hypothesis (H3) is derived from the opportunity structure perspective. It posits that in addition to the abovementioned factors, partnership decisions are strongly influenced by characteristics of the local marriage market that affect the probability of an individual's meeting someone from another group. Regarding ethnic minorities, we expect the group size and share of the majority population in the municipality of residence to be among the important predictors. We expect members of numerically larger minority groups to have better chances of finding a coethnic partner, and hence, to exhibit a lower rate of exogamy. Conversely, a higher proportion of the majority 
population in the municipality of residence is expected to increase the rate of mixed partnership formation among minority groups.

Our fourth hypothesis (H4) relates to socioeconomic differentials in mixed partnership formation. In accord with the predictions of social exchange theory, we hypothesise that minority group members with higher educational status could trade their socioeconomic status for connections with the majority population. This leads us to expect a positive association between educational level and the rate of ethnic heterogamy among the minority population. A positive relationship also follows from the assimilation perspective, according to which minority group members with high educational attainment should be in a better position to overcome the structural and cultural barriers that separate ethnic minorities from the majority population. However, we are aware that other factors, such as changes in the relative position of minority groups and the majority population in Estonia during the $20^{\text {th }}$ century, may lead to different outcomes.

We make use of a two-sided analytical approach to investigate the formation of partnerships from the perspective of the majority population as well. For some hypotheses this leads to the expectation of different, though substantively complementary, results. For instance, for $\mathrm{H} 1$ we anticipate a negative rather than positive association between migrant background and mixed partnership formation among the majority population. For $\mathrm{H} 3$ an elevated rather than reduced rate of mixed partnership formation can be expected in areas with a high concentration of the minority population. For H4 social exchange theory leads us to anticipate a negative rather than positive association between educational attainment and the likelihood of forming a mixed union. At the same time, mixed parentage and early proficiency in a language other than that of one's own group are expected to increase the probability of mixed partnership formation among the majority population as well.

Finally, the inclusion of women and men in the analysis provides evidence for gender-specificity in the formation of mixed partnerships. We anticipate that the hypothesised patterns are, to a large extent, similar for both sexes. However, against the backdrop of previous research, some evidence of gender differences seems plausible. 


\section{Data and analytical approach}

The data for this study comes from the Estonian Generations and Gender Survey (2004/2005), and the Estonian Family and Fertility Survey $(1994,1997){ }^{9}$ Both surveys collected detailed histories of partnership formation and dissolution, childbearing, education, employment, and migration. The surveys were based on nationally representative probability samples of the resident population, with a reduced sampling rate for men. The samples were selected using a single-stage random procedure; the response rates were respectively $70 \%$ (GGS) and $85 \%$ (FFS). After merging the two datasets, the combined sample includes 10,031 women and 5,327 men born between 1924 and 1983. Further information on the surveys is available from methodological reports and other publications (EKDK 1995, 1999; Katus, Puur, and Põldma 2008).

In order to define ethnically mixed partnerships - either cohabitation or marriage we used the self-reported ethnicity of the respondent and his/her partner. We distinguished three main types of partnerships. A minority-majority partnership was defined as marriage or cohabitation of an ethnic minority individual (non-Estonian) with a member of the majority group (ethnic Estonian). A minority-minority union was defined as a union between partners who both belong to ethnic minority groups; majority-majority unions are those in which both partners are ethnic Estonians. In most parts of this study we use the terms 'mixed,' 'interethnic,' and 'exogamous' partnership interchangeably to denote unions between members of the majority and minority populations. The terms 'coethnic' and 'endogamous' are also used synonymously.

We apply a two-sided design in the empirical analysis. This means that we analyse subsamples for minority and majority populations separately. For both groups we investigate the factors that are associated with the likelihood of forming endogamous and exogamous unions. From the substantive point of view, the two-sided approach allows us to examine the extent to which factors shaping the formation of mixed partnerships vary across minority and majority groups.

To analyse the abovementioned transitions we used piecewise constant proportional hazards event history models, estimated separately for interethnic and coethnic unions. Table 1 presents the number of respondents, exposure time, and partnership transitions disaggregated by minority and majority groups. ${ }^{10}$

\footnotetext{
${ }^{9}$ Due to budget constraints, the male survey of the Estonian FFS was carried out three years after the female survey. The survey methodology, including the range of birth cohorts of the target population, was similar for the male and female surveys. In the Estonian GGS, data for women and men was collected simultaneously.

${ }^{10}$ Same information by control variables and ethnic groups is included in the Appendix (Table A-1).
} 
Table 1: Number of respondents, exposure time, and events by ethnic group and gender, Estonia, birth cohorts 1924-1983

\begin{tabular}{|c|c|c|c|c|c|c|}
\hline \multirow[t]{2}{*}{ Population group } & \multirow[t]{2}{*}{$\begin{array}{l}\text { Number of } \\
\text { respondents }\end{array}$} & \multirow[t]{2}{*}{$\begin{array}{l}\text { Exposure time } \\
\text { (number of } \\
\text { person-months) }\end{array}$} & \multicolumn{3}{|c|}{$\begin{array}{l}\text { Number of events } \\
\text { (transition to first partnership) }\end{array}$} & \multirow[t]{2}{*}{$\begin{array}{l}\text { Ratio } \\
\text { (Interethnic to } \\
\text { coethnic) }\end{array}$} \\
\hline & & & All & Interethnic & Coethnic & \\
\hline Minority women & 3,589 & 326,652 & 3,358 & 364 & 2,994 & 0.12 \\
\hline First generation & 2,306 & 219,269 & 2,223 & 228 & 1,995 & 0.11 \\
\hline Second generation & 863 & 70,168 & 746 & 74 & 672 & 0.11 \\
\hline Third+ generation/native & 420 & 37,215 & 389 & 62 & 327 & 0.19 \\
\hline Minority men & 1,791 & 201,546 & 1,614 & 155 & 1,459 & 0.11 \\
\hline First generation & 1,006 & 116,159 & 973 & 92 & 881 & 0.10 \\
\hline Second generation & 599 & 64,357 & 480 & 38 & 442 & 0.09 \\
\hline Third+ generation/native & 186 & 21,030 & 161 & 25 & 136 & 0.18 \\
\hline Majority women & 6,442 & 658,374 & 5,833 & 412 & 5,421 & 0.08 \\
\hline First generation & 264 & 26,575 & 254 & 93 & 161 & 0.58 \\
\hline Second generation & 109 & 11,624 & 97 & 30 & 67 & 0.45 \\
\hline Third+ generation/native & 6,069 & 620,175 & 5,482 & 289 & 5,193 & 0.06 \\
\hline Majority men & 3,536 & 430,691 & 3,097 & 235 & 2,862 & 0.08 \\
\hline First generation & 117 & 15,194 & 113 & 34 & 79 & 0.43 \\
\hline Second generation & 66 & 7,436 & 58 & 11 & 47 & 0.23 \\
\hline Third+ generation/native & 3,353 & 408,061 & 2,926 & 190 & 2,736 & 0.07 \\
\hline
\end{tabular}

Note: Time at risk starts at age 15; censoring occurs at interview date, the respondent's $45^{\text {th }}$ birthday, or at the start of a competing partnership.

Source: Estonian FFS and GGS, authors' calculations.

For each transition investigated, we estimated a series of main effects models. For partnership formation, the first model (M1) included process time, birth cohort, and migrant generation. ${ }^{11}$ In the next step (M2a and M2b), covariates pertaining to minority-majority parentage and early exposure to the majority language were added. In the third step (M3), we included covariates in order to account for the influence of opportunity structure (size of the minority group in the country, the proportion of the majority population in the municipality of residence, and type of settlement). In the final step (M4), we added controls for educational attainment and labour market status. In the stepwise inclusion of control variables, our main interest is in the change occurring in the effect of migrant generation. The proportion of the majority population in the municipality of residence, type of settlement, educational attainment, and labour market status were specified as time-varying covariates; other covariates were time-

${ }^{11}$ The respondents were classified into three groups: first, second, and third generation. The first generation refers to those who were born in a foreign country. The second generation is defined as those who were born in the country of residence but who had at least one parent born abroad. The third or higher generations are those who themselves and whose parents were born in the country of residence. For the minority population, the latter category also includes the descendants of historical minorities (mainly Russians) whose ancestors had settled in Estonia before the Second World War (Katus, Puur, and Sakkeus 2000). 
fixed. In the two-sided approach, the size of the minority group was not applicable to the models for the majority population; therefore, some other variables were specified for the latter.

Models were fitted separately for women and men, which allows us to discern the gender-specificity of the observed patterns. The results, produced as maximum likelihood estimates of parameter effects, are presented in the form of hazard ratios.

\section{Results}

\subsection{Formation of partnerships among the minority population}

Table 2 presents the results from a series of proportional hazards models indicating the probability that ethnic minority women and men would enter a partnership with a majority partner. The dependent variable in the models is the rate of entry into an exogamous first partnership. Exposure was measured in monthly increments, starting at age 15. The respondents were followed until their entry into an exogamous first partnership, or censoring at entry into their first union with a minority partner, the interview, or the respondent's $45^{\text {th }}$ birthday, whichever event occurred first.

The initial model (M1) includes the migrant generation and birth cohort, as well as the duration variable (the latter is not shown in the table). The results for minority women (Panel A) indicate that belonging to a third or higher generation of migrants markedly $(+71 \%)$ increases the chance of partnering with majority men, relative to their first-generation peers (the reference group). By contrast belonging to the second generation makes no statistically significant difference in the likelihood of entering into a mixed union with an Estonian partner.

In the second step (Models M2a and M2b), we added covariates pertaining to minority-majority parentage and early exposure to the majority language. As expected, mixed parentage almost doubled $(+82 \%)$ the likelihood of partnering with Estonian men. ${ }^{12}$ An even stronger link was found between exogamous unions and the language variables. Exposure to the majority language in the parental family triples the probability that a minority woman would partner with an ethnic Estonian, while enrolment in a majority-language school leads to a difference 3.6 times greater than the reference group (minority women who were enrolled in minority-language schools).

12 In additional models (available upon request), we found that for minority women and men alike, the observed result for mixed parentage is driven by having an ethnic Estonian father. The hazard ratio for having an Estonian mother is smaller and fails to reach the level of statistical significance in Model M2a. 
Table 2: Hazard ratios for the transition to an interethnic first partnership, from proportional hazards models, Estonia, minority population, birth cohorts 1924-1983

\begin{tabular}{|c|c|c|c|c|c|c|c|c|c|c|}
\hline \multirow{2}{*}{ Variable } & \multicolumn{5}{|c|}{ a) Women } & \multicolumn{5}{|c|}{ b) Men } \\
\hline & M1 & M2a & M2b & M3 & M4 & M1 & M2a & M2b & M3 & M4 \\
\hline \multicolumn{11}{|l|}{ Migrant generation/status } \\
\hline Third generation/native & $1.71 * * *$ & $1.44^{* *}$ & 1.04 & 0.98 & 1.00 & 1.38 & 1.18 & 0.77 & 0.74 & 0.71 \\
\hline Second generation & 1.08 & 1.05 & 0.86 & 0.79 & 0.77 & 0.69 & 0.69 & 0.62 ** & 0.62 ** & $0.61^{* *}$ \\
\hline First generation & 1 & 1 & 1 & 1 & 1 & 1 & 1 & 1 & 1 & 1 \\
\hline \multicolumn{11}{|l|}{ Birth cohort } \\
\hline $1924-1929$ & 0.69 * & 0.71 & 0.66 * & 0.62 ** & 0.64 ** & 0.62 & 0.63 & 0.69 & 0.74 & 0.77 \\
\hline 1930-1939 & 1.10 & 1.11 & 1.04 & 1.00 & 1.02 & 0.75 & 0.75 & 0.79 & 0.79 & 0.78 \\
\hline $1940-1949$ & $1.43^{* *}$ & $1.44^{* *}$ & 1.33 * & 1.27 & 1.30 & 0.81 & 0.81 & 0.79 & 0.71 & 0.71 \\
\hline 1950-1959 & 1 & 1 & 1 & 1 & 1 & 1 & 1 & 1 & 1 & 1 \\
\hline $1960-1969$ & 1.11 & 1.13 & 1.20 & 1.16 & 1.14 & 1.11 & 1.06 & 1.26 & 1.32 & 1.36 \\
\hline $1970-1979$ & 1.02 & 1.08 & 1.15 & 1.12 & 1.16 & 0.78 & 0.78 & 0.67 & 0.68 & 0.72 \\
\hline $1980-1983$ & 1.12 & 1.17 & 1.08 & 1.22 & 1.47 & 1.07 & 1.08 & 1.15 & 1.03 & 1.09 \\
\hline \multicolumn{11}{|l|}{ Mixed parentage } \\
\hline No & & 1 & 1 & 1 & 1 & & 1 & 1 & 1 & 1 \\
\hline Yes & & 1.82 ** & 1.06 & 1.03 & 1.08 & & $1.87^{\star}$ & 0.67 & 0.73 & 0.77 \\
\hline \multicolumn{11}{|c|}{$\begin{array}{l}\text { Majority language at parental } \\
\text { home }\end{array}$} \\
\hline No & & & 1 & 1 & 1 & & & 1 & 1 & 1 \\
\hline Yes & & & $3.03^{* * *}$ & $1.77^{\star \star \star}$ & 1.69 *** & & & $6.18^{* * *}$ & $3.66^{\star \star \star}$ & $3.65^{* \star *}$ \\
\hline \multicolumn{11}{|l|}{ Majority language at school } \\
\hline No & & & 1 & 1 & 1 & & & 1 & 1 & 1 \\
\hline Yes & & & $3.64 * * *$ & 2.22 *** & 2.39 *** & & & $3.02 * * *$ & $1.85^{* \star *}$ & $2.09 * *$ \\
\hline \multicolumn{11}{|l|}{ Minority group size } \\
\hline Size(ln) & & & & $0.91^{\star \star *}$ & $0.91^{* \star *}$ & & & & $0.86^{* \star *}$ & $0.87^{* * *}$ \\
\hline \multicolumn{11}{|l|}{ Settlement type } \\
\hline Urban & & & & 1 & 1 & & & & 1 & 1 \\
\hline Rural & & & & 1.18 & 1.10 & & & & 1.19 & 1.18 \\
\hline \multicolumn{11}{|l|}{$\begin{array}{l}\text { Share of majority in the } \\
\text { municipality of residence }\end{array}$} \\
\hline Under $30 \%$ & & & & 1 & 1 & & & & 1 & 1 \\
\hline $30-69 \%$ & & & & 1.59 *** & 1.52 *** & & & & 2.29 *** & $1.85^{* * *}$ \\
\hline $70+\%$ & & & & $3.10^{* \star *}$ & $3.08^{* \star *}$ & & & & 5.02 *** & $4.13^{* * *}$ \\
\hline \multicolumn{11}{|l|}{ Educational attainment } \\
\hline Basic & & & & & 0.88 & & & & & 1.17 \\
\hline Upper secondary & & & & & 1 & & & & & 1 \\
\hline Vocational & & & & & 1.39 ** & & & & & 1.23 \\
\hline Tertiary & & & & & 0.99 & & & & & 1.41 \\
\hline \multicolumn{11}{|l|}{ Activity status } \\
\hline Employed & & & & & 1 & & & & & 1 \\
\hline In education & & & & & $0.51^{* * *}$ & & & & & $0.59 * * *$ \\
\hline Other & & & & & $1.72^{\star *}$ & & & & & $0.31^{* \star *}$ \\
\hline
\end{tabular}

Note: ${ }^{* *} p<0.01,{ }^{* *} p<0.05,{ }^{*} p<0.1$. Time at risk starts at age 15 ; censoring occurs at interview date, the respondent's $45^{\text {th }}$ birthday, or at entry into minority-minority partnership.

Source: Estonian FFS and GGS, authors' calculations.

An interesting finding relates to the change in the effect of the migrant generation that follows the inclusion of the aforementioned variables in the model. Adding the control for mixed parentage reduces the hazard ratio for third- and higher-generation women from $71 \%$ to $44 \%$. The inclusion of additional controls for early exposure to the 
majority language produces a further reduction in the hazard ratio, which basically eliminates the difference between third- and higher-generation women and the reference group (the first generation). The change observed for second-generation migrants is smaller but runs in the same direction. Although the difference from the reference group does not reach the level of statistical significance, when mixed parentage and the language variables are considered, second-generation minority women exhibit a reduced rather than elevated likelihood of partnering with an Estonian man.

Another noteworthy result emerges from the comparison of Models M2a and M2b. It suggests that the effect of mixed minority-majority parentage, visible in Model M2a, operates almost exclusively via early exposure to the majority language. Supporting this interpretation, the inclusion of the language variables in the model renders the effect of mixed parentage statistically insignificant (Model M2b). A stepwise inclusion of the language variables (not shown in Table 2) revealed that the reduction in the effect of parentage was driven by exposure to the majority language in the parental home, as one might expect. By contrast, adding enrolment in an Estonian-language school produced only a small reduction in the hazard ratio for minority-majority parentage. Furthermore, the persistence of strong and statistically significant effects for both language variables included in the models suggests that exposure to the host country language within the parental family and at school only partly overlaps. ${ }^{13}$

In the third step (Model M3), we included three additional covariates in order to account for the influence of opportunity structure. In accord with expectations, the size of the minority group within the country exhibits a negative association with mixed partnership formation. Being a member of a larger group significantly reduces the chances that a minority woman would partner with an Estonian man. Somewhat surprisingly, the results do not reveal a significant effect of type of settlement. For ethnic minority women, residence in rural areas only slightly increases the likelihood of exogamous partnership, and the difference from the reference category is not statistically significant. Against that backdrop the population composition of the municipality of residence exerts a much stronger influence on women's partnership choices. The modelling results indicate that residence in areas with a higher proportion of the majority population more than triples the chances that minority women would form partnerships with Estonian men. Notwithstanding its strong impact on partnership choices, consideration of the opportunity structure barely affected the hazard ratios for the migrant generations. Nevertheless, a visible reduction occurred in the effect of our language variables, although it still remained quite strong and statistically significant.

\footnotetext{
${ }^{13}$ To check the robustness of our findings, we reran the models with individuals of mixed parentage removed from the working sample. The results, including those pertaining to the language variables, were only slightly altered.
} 
This suggests that the influence of early exposure to the Estonian language on partnership choice may be partially mediated by the opportunity structure.

In the final step (Model M4), we added controls for education and labour market status. For educational attainment, the results do not reveal any clear pattern. Minority women with vocational education display an elevated likelihood $(+39 \%)$ of exogamous partnership, in comparison with their counterparts with upper secondary education; the hazard ratios for tertiary and basic education are not significantly different from the reference group. Regarding activity status, being neither employed nor enrolled in education markedly increases the chances of partnering with majority men. ${ }^{14}$ Comparison with the previous model reveals only a marginal change in the estimates for our main explanatory variable - migrant generation. In the final model, the likelihood of partnering with majority men is virtually identical for third- and firstgeneration minority women. Neither do we observe a statistically significant difference between the second generation and the reference category. This implies that the addition of controls fully accounts for the intergenerational differences in the likelihood of interethnic unions observed in the initial model.

For the covariates of main interest, the modelling results for minority men (Table 2, Panel B) exhibit an overall similarity to those reported above for minority women, but with some differences. In most models second-generation men exhibit a lower likelihood of forming an ethnically mixed union relative to their first-generation peers. Unlike for women, the difference from the reference group reaches the level of statistical significance $(-39 \%$ in the final model). After controlling for mixed parentage and the language variables, the negative relationship extends to the third generation, although the difference from the first generation is not statistically significant. The effects of most control variables corroborate the results for minority women. Mixed minority-majority parentage significantly increases the chances that minority men will enter an exogamous partnership. As it does for minority women, the effect of mixed parentage operates via early proficiency in the majority language. With regard to opportunity structure, a larger minority group inhibits entry into mixed partnerships, whereas residence in municipalities with a high proportion of ethnic Estonians has the opposite effect. None of the differences between educational groups is statistically significant for minority men, but unlike their female counterparts, those with tertiary education exhibit the highest hazard ratio. Not surprisingly, economic inactivity is incompatible with union formation for men.

When minority-majority unions constitute a relatively small part of all unions, the results for endogamous partnerships will be shaped by the overall pattern of union

\footnotetext{
${ }^{14}$ The effect of activity status seems to be driven by so-called marriages in which the woman is expecting a child at the time the union is formed. The inclusion of an additional control for parity-pregnancy status in the model (not shown in Table 2) renders the effect of activity status statistically insignificant.
} 
formation. This may be an additional reason why the results pertaining to endogamous partnerships attract little interest in analyses of mixed partnerships and often go unreported. However, in this study we decided to look into endogamous unions in order to ascertain whether the results complement the findings reported above on mixed partnerships. Table A-2 in the Appendix presents estimates from models for minorityminority partnerships. To obtain these estimates minority respondents were followed from age 15 until entry into an endogamous first partnership, or censoring at entry into their first union with a majority partner, the interview, or the respondent's $45^{\text {th }}$ birthday.

In all models, for women and men alike, the difference between migrant generations is small and does not reach the level of statistical significance. Regarding the control variables, early exposure to the majority language significantly reduces the probability of coethnic unions, although there are some differences between minority women and men in terms of the relative importance of the parental home and school context. As for the impact of the opportunity structure, residence in rural areas and municipalities with a high proportion of the majority population is found to significantly inhibit entry into coethnic unions among the minority population. The differences related to higher education are not large; having a basic education appears to systematically reduce the probability of endogamous partnership formation for both sexes, relative to the reference group. Finally, it is interesting to note that in contrast to interethnic unions, being neither employed nor enrolled in education does not increase the likelihood that minority women would enter into unions with coethnic partners.

\subsection{Partnership formation among the majority population}

Table 3 presents the estimates of the probability that ethnic majority women and men would form an interethnic first union, which were obtained from proportional hazards models. The specification of the models is comparable to that applied in the previous subsection for the minority population. ${ }^{15}$ We started with a model that included the migrant generation and birth cohort, and then gradually expanded it by including covariates pertaining to the parental family and minority language, opportunity structure, and sociodemographic characteristics.

${ }^{15}$ The variable measuring the size of the ethnic minority group within the country is not applicable to the majority population and was eliminated from the models. 
Table 3: Hazard ratios for the transition to an interethnic first partnership, from proportional hazards models, Estonia, majority population, birth cohorts 1924-1983

\begin{tabular}{|c|c|c|c|c|c|c|c|c|c|c|}
\hline \multirow{2}{*}{ Variable } & \multicolumn{5}{|c|}{ a) Women } & \multicolumn{5}{|l|}{ b) Men } \\
\hline & M1 & M2a & M2b & M3 & M4 & M1 & M2a & M2b & M3 & M4 \\
\hline \multicolumn{11}{|l|}{ Migrant generation/status } \\
\hline Third generation/native & 1 & 1 & 1 & 1 & 1 & 1 & 1 & 1 & 1 & 1 \\
\hline Second generation & 5.24 *** & 2.64 *** & $2.28^{* * *}$ & 2.02 *** & $1.99 * * *$ & $3.18^{* * *}$ & 1.43 & 0.97 & 0.91 & 0.99 \\
\hline First generation & $8.03^{* * *}$ & 5.31 *** & 4.06 *** & $3.50^{\text {*** }}$ & $3.42^{* * *}$ & $4.85^{* * *}$ & 3.19 *** & $1.75^{* *}$ & 1.65 * & $1.51 *$ \\
\hline \multicolumn{11}{|l|}{ Birth cohort } \\
\hline $1924-1929$ & 0.64 ** & 0.82 & 0.86 & 0.81 & 0.78 & 0.58 * & 0.62 * & 0.56 ** & 0.56 ** & $0.57^{\text {** }}$ \\
\hline $1930-1939$ & $0.67^{\star \star *}$ & 0.75 * & 0.77 * & $0.74^{* \star}$ & $0.70^{* *}$ & 0.73 & 0.82 & 0.77 & 0.75 & 0.75 \\
\hline $1940-1949$ & $0.73^{\star *}$ & 0.78 & 0.82 & 0.81 & 0.79 & 0.76 & 0.77 & 0.79 & 0.77 & 0.77 \\
\hline $1950-1959$ & 1 & 1 & 1 & 1 & 1 & 1 & 1 & 1 & 1 & 1 \\
\hline $1960-1969$ & 0.84 & 0.86 & 0.90 & 0.88 & 0.91 & 0.76 & 0.74 & 0.76 & 0.76 & 0.79 \\
\hline $1970-1979$ & 0.84 & 0.88 & 0.94 & 0.87 & 0.89 & 0.70 & 0.64 * & $0.58^{* *}$ & 0.65 * & 0.60 ** \\
\hline $1980-1983$ & 1.20 & 1.10 & 1.21 & 1.14 & 1.25 & 1.42 & 1.39 & 1.19 & 1.30 & 1.33 \\
\hline \multicolumn{11}{|l|}{ Mixed parentage } \\
\hline No & & 1 & 1 & 1 & 1 & & 1 & 1 & 1 & 1 \\
\hline Yes & & $3.57^{* * *}$ & 3.04 *** & $3.07^{* * *}$ & $3.08^{* \star *}$ & & 3.69 *** & $1.79^{* *}$ & $1.87^{\star \star}$ & $1.93^{* \star *}$ \\
\hline \multicolumn{11}{|c|}{$\begin{array}{l}\text { Minority language at parental } \\
\text { home }\end{array}$} \\
\hline No & & & 1 & 1 & 1 & & & 1 & 1 & 1 \\
\hline Yes & & & $1.56^{* *}$ & $1.43^{*}$ & 1.40 & & & $2.98^{* * *}$ & $2.51^{\star \star *}$ & $2.11^{\star \star *}$ \\
\hline \multicolumn{11}{|l|}{ Minority language at school } \\
\hline No & & & 1 & 1 & 1 & & & 1 & 1 & 1 \\
\hline Yes & & & $2.26^{* \star \star}$ & $1.94^{\star \star *}$ & $1.99^{* \star *}$ & & & $3.09^{* \star *}$ & $2.70^{* \star *}$ & $2.30^{* \star *}$ \\
\hline \multicolumn{11}{|l|}{ Settlement type } \\
\hline Urban & & & & 1 & 1 & & & & 1 & 1 \\
\hline Rural & & & & 1.10 & 1.01 & & & & 0.87 & 0.86 \\
\hline \multicolumn{11}{|l|}{$\begin{array}{l}\text { Share of majority in the } \\
\text { municipality of residence }\end{array}$} \\
\hline Under $30 \%$ & & & & 1 & 1 & & & & 1 & 1 \\
\hline $30-69 \%$ & & & & 0.64 ** & 0.62 *** & & & & 0.83 & $0.48 * * *$ \\
\hline $70+\%$ & & & & $0.38^{* * *}$ & $0.38^{* \star *}$ & & & & $0.41^{* * *}$ & 0.22 *** \\
\hline \multicolumn{11}{|l|}{ Educational attainment } \\
\hline Basic & & & & & 1.04 & & & & & 0.98 \\
\hline Upper secondary & & & & & 1 & & & & & \\
\hline Vocational & & & & & 1.06 & & & & & 1.25 \\
\hline Tertiary & & & & & 1.21 & & & & & 0.92 \\
\hline \multicolumn{11}{|l|}{ Activity status } \\
\hline Employed & & & & & 1 & & & & & 1 \\
\hline In education & & & & & 0.42 *** & & & & & 0.32 *** \\
\hline Other & & & & & 0.91 & & & & & 0.19 *** \\
\hline
\end{tabular}

Note: ${ }^{* *} p<0.01,{ }^{* *} p<0.05,{ }^{*} p<0.1$. Time at risk starts at age 15 ; censoring occurs at interview date, the respondent's $45^{\text {th }}$ birthday, or at entry into majority-majority partnership.

Source: Estonian FFS and GGS, authors' calculations.

The results indicate that among majority women, a migrant background entails a markedly increased probability of partnering with minority men (Panel A). In the initial model (M1), ethnic Estonian women who were born abroad (first-generation return migrants) are eight times more likely to enter into a mixed partnership than their counterparts who, along with their parents, were born in Estonia. The results also show 
that the influence of migrant background is not restricted to the first generation but extends to the children of return migrants. In the initial model majority women whose parents were born abroad (mainly in Russia) exhibit chances of mixed union formation five times higher than the reference group. The stepwise inclusion of covariates in the model gradually reduces the effect of migrant background but does not fully explain the differences associated with it. A comparison of estimates from Models M2a-M4 reveals that the largest reduction in the effect of migrant generation follows the inclusion of mixed parentage into the model. ${ }^{16}$ This lends support to the view that among the majority population, the effect of migrant background operates to a large extent via socialisation in the parental home.

Regarding the effects of the control variables, ethnically mixed parentage and early exposure to the minority language enhance the probability that majority women would enter into an exogamous partnership. However, unlike for minority groups, the inclusion of language variables in the models does not render the effect of mixed parentage insignificant. We think that this variation in outcomes reflects the historical context, which gave rise to an atypical relationship between the minority and majority languages. From the mid-1940s until the turn of the 1990s, the minority language (Russian) was promoted in Estonia as the main language of interethnic communication. As a consequence, for most birth cohorts included in this study, the majority population was systematically exposed to the minority language, with exposure being related to mixed parentage only to a limited extent. By contrast, the modest role of the majority language (Estonian) in interethnic communication prior to the 1990s may explain a much closer link between mixed parentage and exposure to the Estonian language among the minority population, as reported in the previous section.

Residence in municipalities with a high concentration of the minority population significantly increases the propensity of Estonian women to enter mixed unions. In the final model, residence in municipalities where the proportion of minority groups amounts to $70 \%$ or more of the total population more than doubles the likelihood of mixed partnerships for majority women. Consistent with findings for minority women, the type of settlement (urban vs. rural) makes no significant difference in partner selection. The inclusion of controls for educational attainment and activity status in the final model (M4) does not result in a major change in the effect of our main explanatory variable (migrant background). Nonetheless, a minor reduction in the hazard ratio renders the effect of the minority language in the parental home statistically insignificant in these models. Likewise, neither high nor low educational attainment

\footnotetext{
${ }^{16}$ Additional models (available upon request) showed that among the majority population the effect of ethnically mixed parentage is driven almost equally by having a minority father or mother (both effects are statistically significant). Notably, this pattern differs from that reported in the previous section for the minority population, among which the paternal influence prevailed.
} 
makes a significant difference in the likelihood of majority women's forming a mixed union.

The results for majority men are also presented in Table 3 (Panel B). The overall patterns are fairly similar to those reported for majority women. Regarding the covariate of main interest, the effect of migrant background appears less pronounced among majority men. For the latter, having foreign-born parents and thus being secondgeneration return migrants makes no significant difference in most models in the likelihood of a mixed union relative to the reference category (third generation or native). Majority men who are born abroad (first-generation return migrants) exhibit a significantly higher likelihood of mixed partnership formation, but the difference from the reference group is smaller than that reported for women. We assume that the observed weaker effect of migrant background may be related to greater mobility, which resulted in men's more frequently going abroad. ${ }^{17}$ Higher participation in international migration evidently exposed men to interethnic partnerships irrespective of migrant background, which diminished the role of the latter.

The findings pertaining to endogamous partnerships complement those reported for ethnically mixed partnerships (Table A-3 in the Appendix). According to the results, migrant background entails a reduced likelihood of endogamous unions for majority women. Estonian women who belong to the second generation of return migrants exhibit a systematically lower rate of forming a coethnic union, relative to the reference group ( $-30 \%$ in the final model). For Estonian women who were born outside the country (first-generation return migrants), the reduced likelihood can be observed in the initial model (M1) but is removed following the consideration of early exposure to the minority language (Model M2b). In particular, enrolment in a minority language school seems to be associated with a noticeably reduced likelihood of entering an endogamous partnership. Consistent with findings reported in the previous section, residence in municipalities with a high concentration of minority groups reduces the chances of forming a majority-majority partnership. ${ }^{18}$ Differences in the rate of forming endogamous partnerships associated with educational attainment appear small, except for basic education, which reduces the probability of coethnic unions $(-20 \%$ in the final model).

17 The comparison of migration histories lends support to this assertion. Among Estonian GGS majority respondents, the proportion of men who ever participated in international migration is nearly four times that of women (Katus, Puur, and Põldma 2008). We think that the gender difference reflects to a large extent the effect of compulsory military service during the post-war decades, which Estonian men were usually sent to perform in other regions of the former Soviet Union. An important effect of military service and veteran status on mixed partnership formation has been previously reported in American studies (Jacobs and Labov 2002; Fryer 2007).

18 In additional models controlling for migration history rendered the effect of opportunity structure insignificant. This suggests that among the majority population the effect of opportunity structure is, to a large extent, driven by the experience of Estonians who were born abroad. 
In accord with findings reported for exogamous unions, the effect of migrant background is weaker for majority men and fails to reach the level of significance in most models. As noted above, this may be due to more intensive cross-border mobility, which exposed men to interethnic partnerships irrespective of migrant background. With regard to mixed parentage, early proficiency in the minority language, and the composition of the population in the municipality of residence, majority men exhibit associations with entry into endogamous partnerships similar to those reported for women. Unlike their female counterparts, majority men show a significant positive association between educational attainment and the rate of endogamous partnership formation. We regard this relationship as a manifestation of the overall pattern of partnership formation, which gives highly educated men an advantage in the marriage market. $^{19}$

\section{Summary and discussion of the findings}

In this study we addressed the formation of ethnically mixed partnerships between the majority and minority populations in Estonia. The aim was to investigate the formation of mixed partnerships from a generational perspective and to provide insight into the factors that facilitate a change in the likelihood of interethnic partnerships across migrant generations. To date, European research on these issues has to a large extent focussed on migrants and their descendants in the western part of the continent. By investigating a different demographic, socioeconomic, and political context, our study contributes to a more comprehensive account of the integration of migrant populations in contemporary Europe. To our knowledge this is the first study in Estonia that employs longitudinal data for the analysis of interethnic partnerships. To obtain a sample size large enough for the analysis we pooled data from two nationally representative event history surveys, the Estonian Family and Fertility Survey, and the Estonian Generations and Gender Survey. To analyse mixed partnerships from the life course perspective we estimated piecewise constant proportional hazards models for the formation of interethnic (minority-majority) and coethnic (minority-minority and majority-majority) first partnerships.

We formulated a series of hypotheses regarding the factors associated with the formation of ethnically mixed minority-majority partnerships. The results generally supported our first hypothesis that, for the minority population, the likelihood of initiating an ethnically mixed partnership increases across migrant generations. This result corroborates previous research that has found a tendency toward a higher

${ }^{19}$ For education-related differences in partnership formation and childbearing in Estonia, see Katus et al. (2007) and Klesment and Puur (2010). 
prevalence of exogamous unions among the second and higher-order generations of immigrants (Lievens 1998; Kalmijn and Tubergen 2006; Lichter, Carmalt, and Qian 2011; Hannemann et al. 2016). However, our analysis also revealed that the increase in mixed partnership formation does not appear to be linear across migrant generations of the minority population in Estonia. After controlling for the influence of confounding factors, second-generation migrants, women and men alike, were found to partner with the majority population at a lower rate than their first-generation predecessors. The reduced propensity of second-generation men to form interethnic unions relative to the first generation is statistically significant.

The observed nonlinearity across migrant generations may have several interlinked causes. On the one hand, contextual features like large-scale post-war immigration to Estonia, the spatial concentration of migrants in specific regions, in which they outnumber the native population, and the linguistic division of the education system, may all have contributed to the absence of growth in the incidence of mixed partnerships with the host population (Tammaru and Kontuly 2011; Lindemann 2013). The latter feature - a linguistically divided education system - is unique among the countries of Northern and Western Europe with large migrant-origin minorities. Moreover, until the restoration of Estonia's sovereignty in 1991, ethnic minority groups enjoyed certain privileges that lessened their motivation to integrate into the host society (Misiunas and Taagepera 1993; Kasekamp 2010). On the other hand, the relatively small (as yet) third generation, which demonstrates a significantly higher rate of mixed partnership formation, includes the descendants of historical minority groups that settled in Estonia before the $20^{\text {th }}$ century. Previous research has shown that the latter are better integrated into the host society than the descendants of post-war migrants (Katus, Puur, and Sakkeus 2000, 2002; Sakkeus 2000), thus partly accounting for the higher rate of mixed partnership formation observed in the third generation. By contrast, in Northern and Western Europe contemporary migrant-origin minorities seldom have roots that extend further back than the mid- $20^{\text {th }}$ century.

In order to provide a more comprehensive account of interethnic partnership formation, we applied a two-sided approach, which extends the analysis to the majority population. In line with expectations, the results for ethnic Estonians reveal a positive association between migrant background and the likelihood of mixed partnership. The probability of forming a majority-minority union was found to be highest among Estonians who were born abroad (return migrants). Although less pronounced, the effect of migrant background extends to Estonians whose parents were born abroad (the descendants of return migrants). Our results are in line with the findings from a previous study on Estonia by van Ham and Tammaru (2011), who drew their evidence from the 2000 census. We share their opinion that socialisation in a foreign country and exposure to noncoethnic peers are the main factors underlying the observed pattern. 
Although the Estonian diaspora to Russia and subsequent return migration may have had some specificity, these findings draw attention to a plausible connection between the growing participation of host populations in international migration and an increase in the incidence of interethnic partnerships (Fligstein 2008; Haandrikman 2014). ${ }^{20}$

According to our second hypothesis, we anticipated that the characteristics of the parental family would play an essential role in partnership decisions. The results support our premise and demonstrate that ethnically mixed ancestry noticeably increases the likelihood of entering into an exogamous union, for both the minority and majority populations. This finding is in accord with the socialisation argument, according to which the family behaviour of migrants and their descendants is shaped by the values, norms and behavioural patterns to which they were exposed during childhood and their formative years (Kulu 2002; Andersson 2004; Milewski 2010). With regard to research on interethnic partnerships, only a few studies to date have demonstrated that family background is also a salient predictor of mixed partnerships among the host population.

Further elaboration of the relationship between the parental family and partnership choices revealed that for the minority population, the effect of mixed parentage mainly operates through exposure to the Estonian language in the parental home. In addition, enrolment in Estonian-language schools markedly increased the chances of having a majority partner. These findings were not surprising since the positive effect of host country language-acquisition on immigrant intermarriage has been reported in several studies (Stevens and Swicegood 1987; Kulczycki and Lobo 2002; Hujink, Verkuyten, and Coenders 2010; De Jesús et al. 2014). More remarkably, consideration of the ancestry of the minority population, and exposure to the majority language in particular, either in the parental home or at school, wholly removed the intergenerational increase in the likelihood of ethnically mixed partnerships. In other words, in Estonia proficiency in the host country language fully accounts for the intergenerational differences in the likelihood of interethnic unions observed in the initial model. This finding corroborates the results of a recent study on fertility and partnership dynamics of migrants and their descendants in Estonia (Rahnu et al. 2016; Puur et al. 2017). By contrast, for members of the majority population, the difference associated with migrant background persisted in the final models. This suggests that among the majority population, the choice between exogamous and endogamous unions may be driven by a more complex array of determinants that were unaccounted for in our study.

Our third hypothesis related to opportunity structure. As anticipated, for members of the minority population we found a negative association between the size of the minority group within the country and the rate of exogamy. Likewise, residence in

${ }^{20}$ Although the migrant background subgroup constitutes a relatively small part of the majority (6\%), its inclusion increases the number of exogamous partnerships among the majority population by $25 \%$. 
municipalities with a high concentration of minority groups significantly reduced the likelihood of partnering with Estonians. For members of the majority population, by contrast, residence in the latter areas increased the chances of forming an ethnically mixed partnership. These findings are consistent with previous research on the structural determinants of ethnic intermarriage (Kalmijn 1998; Kalmijn and van Tubergen 2010). However, unlike earlier studies of mixed partnership formation in Estonia, we did not observe a significant relationship between the type of settlement (urban vs. rural) and the rate of exogamy (van Ham and Tammaru 2011). We think that other variables used in our models, particularly the share of minority and majority populations in the municipality of residence, accounted more precisely for the effect of opportunity structure.

Our fourth hypothesis pertaining to the formation of interethnic partnerships focussed on the role of educational attainment. Our expectations regarding the effect of education were mixed. On the one hand, higher education could have resulted in individuals' being more exposed and open to interethnic partnerships. On the other hand, the social exchange theory predicted a more complex interaction in which members of minority groups are assumed to trade their higher socioeconomic position for the lower social prestige attached to minority status. Our results support neither of these assertions. For both the minority and majority populations the association between educational attainment and partnership formation failed to exhibit a systematic pattern. The rejection of the first assertion implies that in Estonia higher education has not resulted in a preference for mixed partnerships. The refutation of the second assertion suggests that conceptualising the majority and minority populations as dominant and subordinate may be faulty in the Estonian context. The weak effects of educational attainment corroborate previous results reported for Estonia (van Ham and Tammaru 2011) and several other settings (Monden and Smits 2005; Gullickson 2006; Haandrikman 2014).

In this study we also modelled the formation of endogamous partnerships. In general the effects of the variables of main interest (migrant generation, mixed parentage, early exposure to different languages, and opportunity structure) were less pronounced than those reported for exogamous minority-majority unions. This stems from the fact that the modelling results for endogamous partnerships are shaped by overall patterns of partnership formation. Nonetheless, for members of the minority population, early proficiency in the majority language, and residence in rural areas or in municipalities with a high proportion of Estonians were found to significantly reduce the probability of endogamous partnering. For the majority population, the effect of early exposure to the minority language exhibits a very similar effect.

Nevertheless, this study is not without limitations. In a survey-based approach, the constraints imposed by sample size prevented us from distinguishing between various 
ethnic groups within the minority population. This made it impossible to investigate the extent to which cultural similarity to the majority population facilitates the formation of minority-majority unions. However, the predominance of Russians and other Slavic groups renders the diversity of minority groups less significant in Estonia. Another major limitation stems from reliance on self-reported ethnicity in defining minority and majority groups. It is possible that some respondents may have changed their ethnic self-identification relative to the ethnicity of their parents; in particular, such shifts can occur among the offspring of mixed families, who, by definition, face a choice between different identities. This implies that the descendants of immigrants, who are most integrated into the host society, may be included among the majority population, and their partnerships considered endogamous. As a consequence, the incidence of mixed partnerships may be to some extent underreported in our study, especially for third- and higher-generation migrants. However, as these generations constitute a small segment of adults within the minority population in Estonia, we believe that the limitations do not invalidate our main findings.

We think that several important conclusions can be drawn from this analysis. First, the results lend support to the notion that the integration of migrant populations through mixed partnering is a complex and prolonged process. In our study the experience of second-generation migrants provides an example of a stalling trend in the incidence of mixed partnerships between the majority population and migrant groups. With regard to the future, this implies that for very large migrant groups, complete fusion with the majority population over a few generations is not a likely scenario. High rates of endogamous partnering allow minorities to maintain cultural specificity for extended periods. Second, the study drew attention to multiple factors that can hinder or facilitate interethnic partnering. Apart from the size of minority groups and residential proximity to the majority population, the study underscores the salience of early acquisition of the host society language. In comparison, incomplete acquisition of the host country language, which is rooted in historical events, seems to be a paramount contextual feature that distinguishes the descendants of post-war migrants to Estonia from 'typical' second-generation migrants in contemporary Northern and Western Europe. In the policy context this finding calls into question the maintenance of a linguistically divided school system in Estonia. In its present mode the divided school system constitutes a potent mechanism for maintaining the pillarization of the society. Likewise, the results draw attention to residential segregation as another important hindrance to the integration of minority groups into the host society. Third, our results show the role of increasing international mobility, which leads host populations to be more exposed and open to mixed partnership formation. 


\section{Acknowledgements}

The research leading to these results has received support from the Estonian Research Council (grant PRG71) and from the ERA.Net RUS PLUS 2015 (project Rus Fam). Preliminary stages of the work have also benefitted from participation in the European Union's Seventh Framework Programme (FP7/2007-2013) under grant agreement No. 320116 of the Families and Societies research project. 


\section{References}

Alba, R. and Nee, V. (2003). Remaking the American mainstream. Cambridge: Harvard University Press. doi:10.4159/9780674020115.

Alba, R.D. and Golden, R.M. (1986). Patterns of ethnic marriage in the United States. Social Forces 65(1): 202-223. doi:10.1093/sf/65.1.202.

Andersson, G. (2004). Childbearing after migration: Fertility patterns of foreign-born women in Sweden. International Migration Review 38(2): 747-774. doi:10.1111/j.1747-7379.2004.tb00216.x.

Bankston, C.L. and Henry, J. (1999). Endogamy among Louisiana Cajuns: A social class explanation. Social Forces 77(4): 1317-1338. doi:10.1093/sf/77.4.1317.

Becker, G.S. (1981). A treatise on the family. Cambridge: Harvard University Press.

Blau, P.M. and Schwartz, J.E. (1984). Crosscutting social circles: Testing a macrostructural theory of intergroup relations. New York: Academic Press.

Botev, N. (2002). The ethnic composition of families in Russia in 1989: Insights into the Soviet 'nationalities policy.' Population and Development Review 28(4): 681-706. doi:10.1111/j.1728-4457.2002.00681.x.

Çelikaksoy, A. (2012). Intergenerational transmission of interethnic union formation patterns in Sweden. Migration Letters 9(2): 101-114.

Chiswick, B.R. and Houseworth, C. (2011). Ethnic intermarriage among immigrants: Human capital and assortative mating. Review of Economics of the Household 9(2): 149-180. doi:10.1007/s11150-010-9099-9.

Coleman, D.A. (1994). Trends in fertility and intermarriage among immigrant populations in Western Europe as measures of integration. Journal of Biosocial Science 26(1): 107-136. doi:10.1017/S0021932000021106.

Crul, M. and Schneider, J. (2010). Comparative integration context theory: Participation and belonging in new diverse European cities. Ethnic and Racial Studies 33(7): 1249-1268. doi:10.1080/01419871003624068.

Davis, K. (1941). Intermarriage in caste societies. American Anthropologist 43(3): 376395. doi:10.1525/aa.1941.43.3.02a00030.

De Jesús, A., Burgos, G., Almenas, M., and Velez, W. (2014). Puerto Rican intergroup marriage and residential segregation in the U.S.: A multilevel analysis of 
structural, cultural, and economic factors. Journal of Human Behavior in the Social Environment 24(2): 156-178. doi:10.1080/10911359.2014.848689.

Dribe, M. and Lundh, C. (2008). Intermarriage and immigrant integration in Sweden: An exploratory analysis. Acta Sociologica 51(4): 329-354. doi:10.1177/ 0001699308097377.

Dribe, M. and Lundh, C. (2011). Cultural dissimilarity and intermarriage: A longitudinal study of immigrants in Sweden 1990-2005. International Migration Review 45(2): 297-324. doi:10.1111/j.1747-7379.2011.00849.x.

EKDK (1995). Estonian family and fertility survey: Methodological report. Tallinn: Estonian Interuniversity Population Research Centre (Series A, 39).

EKDK (1999). Estonian family and fertility survey: Methodological report of male survey. Tallinn: Estonian Interuniversity Population Research Centre (Series A, 39).

ESA (2017). Statistics Estonia statistical database [electronic resource]. Tallinn: Statistics Estonia. http://pub.stat.ee/px-web.2001/dialog/statfile2.asp.

Fligstein, N. (2008). Euroclash: The EU, European identity, and the future of Europe. Oxford: Oxford University Press.

Fryer, R.G. (2007). Guess who's been coming to dinner? Trends in interracial marriage over the $20^{\text {th }}$ century. Journal of Economic Perspectives 21(2): 71-90. doi:10. 1257/jep.21.2.71.

$\mathrm{Fu}, \mathrm{X}$. (2006). Impact of socioeconomic status on inter-racial mate selection and divorce. The Social Science Journal 43(2): 239-258. doi:10.1016/j.soscij.2006. 02.004 .

$\mathrm{Fu}, \mathrm{X}$. (2008). Interracial marriage and family socio-economic well-being: Equal status exchange or caste status exchange? The Social Science Journal 45(1): 132-155. doi:10.1016/j.soscij.2007.12.008.

Fu, X. and Heaton, T.B. (2008). Racial and educational homogamy: 1980 to 2000. Sociological Perspectives 51(4): 735-758. doi:10.1525/sop.2008.51.4.735.

Furtado, D. and Theodoropoulos, N. (2011). Interethnic marriage: A choice between ethnic and educational similarities. Journal of Population Economics 24(4): 1257-1279. doi:10.1007/s00148-010-0319-7. 
González-Ferrer, A. (2006). Who do immigrants marry? Partner choice among single immigrants in Germany. European Sociological Review 22(2): 171-185. doi:10.1093/esr/jci050.

Gordon, M. (1964). Assimilation in American life. New York: Oxford University Press.

Gullickson, A. (2006). Education and black-white interracial marriage. Demography 43(4): 673-689. doi:10.1353/dem.2006.0033.

Gullickson, A. and Torche, F. (2014). Patterns of racial and educational assortative mating in Brazil. Demography 51(3): 835-856. doi:10.1007/s13524-014-0300-2.

Haandrikman, K. (2014). Binational marriages in Sweden: Is there an EU effect? Population, Space and Place 20(2): 177-199. doi:10.1002/psp.1770.

Haller, W.J., Portes, A., and Lynch, S. (2011). Dreams fulfilled, dreams shattered: Determinants of segmented assimilation in the immigrant second generation. Social Forces 89(3): 733-762. doi:10.1353/sof.2011.0003.

Hannemann, T., Kulu, H., Rahnu, L., Puur, A., Haragus, M., Obućina, O., GonzálezFerrer, A., Neels, K., van den Berg, L., Pailhé, A., Potarca, G., and Bernardi, L. (2016). A comparative study of mixed marriages among natives, immigrants and their descendants in Europe. Stockholm: Stockholm University (FamiliesAndSocieties working paper 56).

Hartung, A., Vandezande, V., Phalet, K., and Swyngedouw, M. (2011). Partnership preferences of the Belgian second generation: Who lives with whom? Advances in Life Course Research 16(4): 152-163. doi:10.1016/j.alcr.2011.09.001.

Heath, A.F. and Cheung, S.Y. (2007). The comparative study of ethnic minority disadvantage. In: Heath, A.F. and Cheung, S.Y. (eds.). Unequal chances: Ethnic minorities in Western labour markets: The Proceedings of the British Academy. Oxford: Oxford University Press and British Academy: 1-44. doi:10.5871/bacad/9780197263860.003.0001.

Holloway, S.R., Ellis, M., Wright, R., and Hudson, M. (2005). Partnering 'out' and fitting in: Residential segregation and the neighbourhood contexts of mixed-race households. Population, Space and Place 11(4): 299-324. doi:10.1002/psp.378.

Huijnk, W., Verkuyten, M., and Coenders, M. (2010). Intermarriage attitude among ethnic minority and majority groups in the Netherlands: The role of family relations and immigrant characteristics. Journal of Comparative Family Studies 41(3): 389-414. 
Hurtado, A. (1995). Variations, combinations, and evolutions: Latino families in the United States. In: Zambrana, R.E. (ed.). Understanding Latino families. London: Sage: 40-61. doi:10.4135/9781483327259.n3.

Huschek, D., de Valk, H.A.G., and Liefbroer, A.C. (2012). Partner choice patterns among the descendants of Turkish immigrants in Europe. European Journal of Population 28(3): 241-268. doi:10.1007/s10680-012-9265-2.

Hwang, S.S., Saenz, R., and Aguirre, B.E. (1997). Structural and assimilationist explanations of Asian American intermarriage. Journal of Marriage and the Family 59(3): 758-772. doi:10.2307/353959.

Jacobs, J.A. and Labov, T.G. (2002). Gender differentials in intermarriage among sixteen race and ethnic groups. Sociological Forum 17(4): 621-646. doi:10.1023/A:1021029507937.

Kalmijn, M. (1993). Trends in black/white intermarriage. Social Forces 72(1): 119146. doi:10.1093/sf/72.1.119

Kalmijn, M. (1998). Intermarriage and homogamy: Causes, patterns, trends. Annual Review of Sociology 24: 395-421. doi:10.1146/annurev.soc.24.1.395.

Kalmijn, M. (2012). The educational gradient in intermarriage: A comparative analysis of immigrant groups in the United States. Social Forces 91(2): 453-476. doi: $10.1093 / \mathrm{sf} / \mathrm{sos} 128$.

Kalmijn, M. and van Tubergen, F. (2006). Ethnic intermarriage in the Netherlands: Confirmations and refutations of accepted insights. European Journal of Population 22(4): 371-397. doi:10.1007/s10680-006-9105-3.

Kalmijn, M. and van Tubergen, F. (2010). A comparative perspective on intermarriage: Explaining differences among national-origin groups in the United States. Demography 47(2): 459-479. doi:10.1353/dem.0.0103.

Kao, G. and Joyner, K. (2006). Do Hispanic and Asian adolescents practice panethnicity in friendship choices? Social Science Quarterly 87(5): 972-992. doi:10.1111/j.1540-6237.2006.00411.x.

Kasekamp, A. (2010). A history of the Baltic states. Basingstoke: Palgrave Macmillan. doi:10.1007/978-0-230-36450-9.

Katus, K. and Puur, A. (2003). Unity and diversity of population development: Baltic and South-Caucasian countries. Tallinn: Estonian Interuniversity Population Research Centre (Series D, 3). 
Katus, K., Puur, A., and Põldma, A. (2008). Estonian family and fertility survey. Second round. Standard tabulations. Tallinn: Estonian Interuniversity Population Research Centre (Series C, 26).

Katus, K., Puur, A., and Sakkeus, L. (2000). The demographic characteristics of national minorities in Estonia. In: Haug, W., Compton, P., and Courbage, Y. (eds.). The demographic characteristics of national minorities in certain European states. Strasbourg: Council of Europe: 29-92.

Katus, K., Puur, A., and Sakkeus, L. (2002). Immigrant population in Estonia. In: Haug, W., Compton, P., and Courbage, Y. (eds.). The demographic characteristics of immigrant populations. Strasbourg: Council of Europe: 131-192.

Katus, K., Puur, A., Põldma, A., and Sakkeus, L. (2007). First union formation in Estonia, Latvia and Lithuania: Patterns across countries and gender. Demographic Research 17(10): 247-300. doi:10.4054/DemRes.2007.17.10.

Klesment, K. and Puur, A. (2010). Effects of education on second births before and after societal transition: Evidence from the Estonian GGS. Demographic Research 22(28): 891-932. doi:10.4054/DemRes.2010.22.28.

Koreinik, K. and Tender, T. (2013). Eesti keeltest rahvaloendustel [Languages and censuses in Estonia]. Emakeele Seltsi Aastaraamat 59: 77-102.

Kulczycki, A. and Lobo, A.P. (2002). Patterns, determinants, and implications of intermarriage among Arab Americans. Journal of Marriage and Family 64(1): 202-210. doi:10.1111/j.1741-3737.2002.00202.x.

Kulu, H. (1997). Eestlaste tagasiränne 1940-1989: Lääne-Siberist pärit eestlaste näitel [Return migration of Estonians 1940-1989: The case of Estonians in Western Siberia]. Helsinki: University of Helsinki.

Kulu, H. (2000). Policy towards the diaspora and ethnic (return) migration: An Estonian case. GeoJournal 51(3): 135-143. doi:10.1023/A:1017504821815.

Kulu, H. (2002). Socialization and residence: Ethnic return migrants in Estonia. Environment and Planning A 34(2): 289-316. doi:10.1068/a34162a.

Kulu, H. and González-Ferrer, A. (2014). Family dynamics among immigrants and their descendants in Europe: Current research and opportunities. European Journal of Population 30(4): 411-435. doi:10.1007/s10680-014-9322-0.

Lanzieri, G. (2012). Mixed marriages in Europe 1990-2010. In: Kim, D.S. (ed.). Crossborder marriage: Global trends and diversity. Seoul: Korea Institute for Health and Social Affairs: 81-122. 
Liang, Z. and Ito, N. (1999). Intermarriage of Asian Americans in the New York City region: Contemporary patterns and future prospects. International Migration Review 33(4): 876-900. doi:10.2307/2547356.

Lichter, D.T., Carmalt, J.H., and Qian, Z. (2011). Immigration and intermarriage among Hispanics: Crossing racial and generational boundaries. Sociological Forum 26(2): 241-264. doi:10.1111/j.1573-7861.2011.01239.x.

Lieberson, S. and Waters, M.C. (1988). From many strands: Ethnic and racial groups in contemporary America. New York: Russell Sage Foundation.

Lievens, J. (1998). Interethnic marriage: Bringing in the context through multilevel modelling. European Journal of Population 14(1): 117-155. doi:10.1023/ A:1006075325546.

Lindemann, K. (2013). Structural integration of young Russian-speakers in post-Soviet contexts: Educational attainment and the transition to the labour market. Tallinn: Tallinn University (Dissertations in Social Sciences 68).

Logan, J.R. and Shin, H.-J. (2012). Assimilation by the third generation? Marital choices of white ethnics at the dawn of the twentieth century. Social Science Research 41(5): 1116-1125. doi:10.1016/j.ssresearch.2012.01.010.

Lucassen, L. and Laarman, C. (2009). Immigration, intermarriage and the changing face of Europe in the post-war period. History of the Family 14(1): 52-68. doi:10.1016/j.hisfam.2008.12.001.

Luuk, M. (2009). Labour market risks of immigrants. In: Saar, E. and Põder, K. (eds.). Immigrant population in Estonia. Tallinn: Statistics Estonia: 92-111.

Merton, R. (1941). Intermarriage and the social structure: Fact and theory. Psychiatry 4(3): 361-374. doi:10.1080/00332747.1941.11022354.

Milewski, N. (2010). Fertility of immigrants: A two-generational approach in Germany. Berlin: Springer. doi:10.1007/978-3-642-03705-4.

Milewski, N. and Hamel, C. (2010). Union formation and partner choice in a transnational context: The case of descendants of Turkish immigrants in France. International Migration Review 44(3): 615-658. doi:10.1111/j.1747-7379.2010. 00820.x.

Misiunas, R. and Taagepera, R. (1993). The Baltic states: Years of dependence 19401990. Berkeley: University of California Press. 
Monden, C. and Smits, J. (2005). Ethnic intermarriage in times of social change: The case of Latvia. Demography 42(2): 323-345. doi:10.1353/dem.2005.0015.

Muttarak, R. and Heath, A. (2010). Who intermarries in Britain? Explaining ethnic diversity in intermarriage patterns. British Journal of Sociology 61(2): 275-305. doi:10.1111/j.1468-4446.2010.01313.x.

Niedomysl, T., Östh, J., and van Ham, M. (2010). Globalisation of marriage fields. Journal of Ethnic and Migration Studies 36(7): 1119-1138. doi:10.1080/ 13691830903488184.

Pavelson, M. and Luuk, M. (2002). Non-Estonians on the labour market: A change in the economic model and differences in social capital. In: Lauristin, M. and Heidmets, M. (eds.). The challenge of the Russian minority: Emerging multicultural democracy in Estonia. Tartu: Tartu University Press: 89-117.

Peach, C. (2005). Social integration and social mobility: Spatial segregation and intermarriage of the Caribbean population in Britain. In: Koury, G.C., Modood, T., and Teles, S.M. (eds.). Ethnicity, social mobility and public policy: Comparing the US and UK. Cambridge: Cambridge University Press: 178-203.

Portes, A., Fernández-Kelly, P., and Haller, W. (2005). Segmented assimilation on the ground: The new second generation in early adulthood. Ethnic and Racial Studies 28(6): 1000-1040. doi:10.1080/01419870500224117.

Portes, A. and Zhou, M. (1993). The new second generation: Segmented assimilation and its variants. The Annals of the American Academy of Political and Social Science 530(1): 74-96. doi:10.1177/0002716293530001006.

Puur, A. (2000). Economic activity in transition: Population of foreign-origin in Estonia in the 1990s. Trames: Journal of the Humanities and Social Sciences 4(3): 286316.

Puur, A., Rahnu, L., Sakkeus, L., Abuladze, L., and Zakharov, S. (2017). Childbearing among first- and second-generation Russians in Estonia against the background of the sending and host countries. Demographic Research 36(41): 1209-1254. doi:10.4054/DemRes.2017.36.41.

Puur, A., Rahnu, L., and Valge, J. (2016). Eesti keel sisserändetuules: Demograafiline tagasivaade 1989-2011 ja edasipilk [Estonian language in the context of immigration: A demographic retrospect of the years 1989-2011 and prospects]. Keel ja Kirjandus 59(4,5): 268-280, 354-372. 
Qian, Z. (1997). Breaking the racial barriers: Variations in interracial marriage between 1980 and 1990. Demography 34(2): 263-276. doi:10.2307/2061704.

Qian, Z., Blair, S.L., and Ruf, S.D. (2001). Asian American interracial and interethnic marriages: Differences by education and nativity. International Migration Review 35(2): 557-586. doi:10.1111/j.1747-7379.2001.tb00029.x.

Qian, Z. and Lichter, D.T. (2001). Measuring marital assimilation: Intermarriage among natives and immigrants. Social Science Research 30(2): 289-312. doi:10.1006/ ssre.2000.0699.

Quillian, L. (1995). Prejudice as a response to perceived group threat: Population composition and anti-immigrant and racial prejudice in Europe. American Sociological Review 60(4): 586-611. doi:10.2307/2096296.

Rahnu, L., Puur, A., Sakkeus, L., and Klesment, M. (2016). Partnership dynamics among migrants and their descendants in Estonia. Demographic Research 32(56): 1519-1566. doi:10.4054/DemRes.2015.32.56.

Rannut, M. (2008). Estonianisation efforts post-independence. International Journal of Bilingual Education and Bilingualism 11(3-4): 57-71.

Rendall, M.S., Tsang, F., Rubin, J.K., Rabinovich, L., and Janta, B. (2010). Contrasting trajectories of labor-market integration between migrant women in Western and Southern Europe. European Journal of Population 26(4): 383-410. doi:10.1007/s10680-010-9214-x.

Roosson, A. (1984). Izmeneniya v sostave semey Estonskoy SSR [Changes in the composition of families in the Estonian SSR]. Sotsiologicheskie Issledovaniya 11(1): 94-97.

Safi, M. (2010). Patterns of immigrant intermarriage in France: Intergenerational marital assimilation? Zeitschrift für Familienforschung 22(1): 89-108.

Sakkeus, L. (1994). The Baltic states. In: Ardittis, S. (ed.). The politics of East-West migration. New York: St. Martin's: 68-85. doi:10.1007/978-1-349-23352-6_4.

Sakkeus, L. (2000). Demographic behaviour patterns of immigrants and national minority of the same ethnic background: Case of Estonia. Trames: Journal of the Humanities and Social Sciences 4(3): 268-285.

Schoen, R. (1986). A methodological analysis of intergroup marriage. Sociological Methodology 16(1): 49-78. doi:10.2307/270919. 
Schoen, R. and Thomas, B. (1989). Intergroup marriage in Hawaii, 1969-1971 and 1979-1981. Sociological Perspectives 32(3): 365-382. doi:10.2307/1389123.

Schoen, R. and Wooldredge, J. (1989). Marriage choices in North Carolina and Virginia, 1969-71 and 1979-81. Journal of Marriage and Family 51(2): 465481. doi: $10.2307 / 352508$.

Song, M. (2010). What happens after segmented assimilation? An exploration of intermarriage and 'mixed race' young people in Britain. Ethnic and Racial Studies 33(7): 1194-1213. doi:10.1080/01419871003625271.

Spörlein, C., Schlueter, E., and van Tubergen, F. (2013). Ethnic intermarriage in longitudinal perspective: Testing structural and cultural explanations in the United States 1880-2011. Social Science Research 43(1): 1-15.

Stevens, G. and Swicegood, G. (1987). The linguistic context of ethnic endogamy. American Sociological Review 52(1): 73-82. doi:10.2307/2095393.

Tammaru, T. and Kontuly, T. (2011). Selectivity and destinations of ethnic minorities leaving the main gateway cities of Estonia. Population, Space and Place 17(5): 674-688. doi:10.1002/psp.623.

Tammaru, T. and Kulu, H. (2003). The ethnic minorities in Estonia: Changing size, composition and location. Eurasian Geography and Economics 44(2): 105-120. doi:10.2747/1538-7216.44.2.105.

Tolsma, J. (2009). Ethnic hostility among ethnic majority and minority groups in the Netherlands: An investigation into the impact of social mobility experiences, the local living environment and educational attainment on ethnic hostility $[\mathrm{PhD}$ thesis]. Nijmegen: Radboud University Nijmegen.

Van Ham, M. and Tammaru, T. (2011). Ethnic minority-majority unions in Estonia. European Journal of Population 27(3): 313-335. doi:10.1007/s10680-0119236-z.

Van Ham, M. and Tammaru, T. (2016). New perspectives on ethnic segregation over time and space: A domains approach. Urban Geography 37(7): 953-962. doi:10.1080/02723638.2016.1142152.

Van Niekerk, M. (2007). Second-generation Caribbeans in the Netherlands: Different migration histories, diverging trajectories. Journal of Ethnic and Migration Studies 33(7): 1063-1081. doi:10.1080/13691830701541580. 
Vermeulen, H. (2010). Segmented assimilation and cross-national comparative research on the integration of immigrants and their children. Ethnic and Racial Studies 33(7): 1214-1230. doi:10.1080/01419871003615306.

Volkov, A. (1989). Etnicheski smeshannye sem'i v SSSR: Dinamika i sostav [Ethnically mixed families in the USSR: Dynamics and composition]. Vestnik Statistiki 7: 12-22.

Wagner, U. and Zick, A. (2006). The relation of formal education to ethnic prejudice: Its reliability, validity and explanation. European Journal of Social Psychology 25(1): 41-56. doi:10.1002/ejsp.2420250105.

Zhou, M. (1997). Segmented assimilation: Issues, controversies, and recent research on the new second generation. International Migration Review 31(4): 975-1008. doi: $10.2307 / 2547421$. 
Puur et al:: The formation of ethnically mixed partnerships in Estonia

\section{Appendix}

\section{Table A-1: Number of respondents, exposure time, and events by control variables and ethnic groups, Estonia, birth cohorts 1924-1983}

a) Minority women

\begin{tabular}{|c|c|c|c|c|c|c|}
\hline \multirow[t]{2}{*}{ Variable } & \multirow[t]{2}{*}{$\begin{array}{l}\text { Exposure time } \\
\text { (number of } \\
\text { person-months) }\end{array}$} & \multirow[t]{2}{*}{$\begin{array}{l}\text { Exposure time } \\
\text { (\%) }\end{array}$} & \multicolumn{3}{|c|}{$\begin{array}{l}\text { Number of events } \\
\text { (transition to first partnership) }\end{array}$} & \multirow{2}{*}{$\begin{array}{l}\text { Ratio } \\
\text { (Interethnic to } \\
\text { coethnic) }\end{array}$} \\
\hline & & & All & Interethnic & Coethnic & \\
\hline \multicolumn{7}{|l|}{ Birth cohort } \\
\hline 1924-1929 & 41,909 & 12.8 & 365 & 33 & 332 & 0.10 \\
\hline 1930-1939 & 70,502 & 21.6 & 666 & 85 & 581 & 0.15 \\
\hline 1940-1949 & 57,647 & 17.6 & 592 & 83 & 509 & 0.16 \\
\hline 1950-1959 & 68,794 & 21.1 & 741 & 69 & 672 & 0.10 \\
\hline 1960-1969 & 50,595 & 15.5 & 622 & 53 & 569 & 0.09 \\
\hline 1970-1979 & 28,381 & 8.7 & 308 & 31 & 277 & 0.11 \\
\hline $1980-1983$ & 8,824 & 2.7 & 64 & 10 & 54 & 0.19 \\
\hline \multicolumn{7}{|l|}{ Mixed parentage } \\
\hline No & 312,098 & 95.5 & 3,204 & 330 & 2,874 & 0.11 \\
\hline Yes & 14,554 & 4.5 & 154 & 34 & 120 & 0.28 \\
\hline \multicolumn{7}{|c|}{$\begin{array}{l}\text { Majority language at parental } \\
\text { home }\end{array}$} \\
\hline No & 306,668 & 93.9 & 3,173 & 286 & 2,887 & 0.10 \\
\hline Yes & 19,984 & 6.1 & 185 & 78 & 107 & 0.73 \\
\hline \multicolumn{7}{|c|}{ Majority language at school } \\
\hline No & 182,726 & 55.9 & 2,642 & 300 & 2342 & 0.13 \\
\hline Yes & 143,926 & 44.1 & 716 & 64 & 652 & 0.10 \\
\hline \multicolumn{7}{|l|}{ Settlement type } \\
\hline Urban & 254,693 & 78.0 & 2,850 & 285 & 2,565 & 0.11 \\
\hline Rural & 71,959 & 22.0 & 508 & 79 & 429 & 0.18 \\
\hline \multicolumn{7}{|c|}{$\begin{array}{l}\text { Share of majority in the } \\
\text { municipality of residence }\end{array}$} \\
\hline Under $30 \%$ & 189,500 & 58.0 & 1,725 & 124 & 1,601 & 0.08 \\
\hline $30-69 \%$ & 99,076 & 30.3 & 1,228 & 117 & 1,111 & 0.11 \\
\hline $70+\%$ & 38,076 & 11.7 & 405 & 123 & 282 & 0.44 \\
\hline \multicolumn{7}{|l|}{ Educational attainment } \\
\hline Basic & 205,194 & 62.8 & 1,421 & 157 & 1,264 & 0.12 \\
\hline Upper secondary & 67,544 & 20.7 & 859 & 88 & 771 & 0.11 \\
\hline Vocational & 41,375 & 12.7 & 874 & 99 & 775 & 0.13 \\
\hline Tertiary & 12,539 & 3.8 & 204 & 20 & 184 & 0.11 \\
\hline \multicolumn{7}{|l|}{ Activity status } \\
\hline Employed & 167,644 & 51.3 & 2,586 & 279 & 2,307 & 0.12 \\
\hline In education & 144,010 & 44.1 & 599 & 59 & 540 & 0.11 \\
\hline Other & 14,998 & 4.6 & 173 & 26 & 147 & 0.18 \\
\hline
\end{tabular}


Table A-1: (Continued)

b) Minority men

\begin{tabular}{|c|c|c|c|c|c|c|}
\hline \multirow[t]{2}{*}{ Variable } & \multirow[t]{2}{*}{$\begin{array}{l}\text { Exposure time } \\
\text { (number of } \\
\text { person-months) }\end{array}$} & \multirow[t]{2}{*}{$\begin{array}{l}\text { Exposure time } \\
\text { (\%) }\end{array}$} & \multicolumn{3}{|c|}{$\begin{array}{l}\text { Number of events } \\
\text { (transition to first partnership) }\end{array}$} & \multirow[t]{2}{*}{$\begin{array}{l}\text { Ratio } \\
\text { (Interethnic to } \\
\text { coethnic) }\end{array}$} \\
\hline & & & All & Interethnic & Coethnic & \\
\hline \multicolumn{7}{|l|}{ Birth cohort } \\
\hline 1924-1929 & 13,286 & 6.6 & 104 & 9 & 95 & 0.09 \\
\hline 1930-1939 & 36,449 & 18.1 & 294 & 28 & 266 & 0.11 \\
\hline 1940-1949 & 33,511 & 16.6 & 280 & 26 & 254 & 0.10 \\
\hline $1950-1959$ & 46,041 & 22.8 & 408 & 38 & 370 & 0.10 \\
\hline 1960-1969 & 39,174 & 19.4 & 341 & 33 & 308 & 0.11 \\
\hline $1970-1979$ & 27,169 & 13.5 & 162 & 18 & 144 & 0.13 \\
\hline $1980-1983$ & 5,916 & 2.9 & 25 & 3 & 22 & 0.14 \\
\hline \multicolumn{7}{|l|}{ Mixed parentage } \\
\hline No & 193,686 & 96.1 & 1,554 & 142 & 1,412 & 0.10 \\
\hline Yes & 7,860 & 3.9 & 60 & 13 & 47 & 0.28 \\
\hline \multicolumn{7}{|c|}{$\begin{array}{l}\text { Majority language at parental } \\
\text { home }\end{array}$} \\
\hline No & 191,066 & 94.8 & 1,529 & 116 & 1,413 & 0.08 \\
\hline Yes & 10,480 & 5.2 & 85 & 39 & 46 & 0.85 \\
\hline \multicolumn{7}{|c|}{ Majority language at school } \\
\hline No & 126,772 & 62.9 & 1,335 & 128 & 1,207 & 0.11 \\
\hline Yes & 74,774 & 37.1 & 279 & 27 & 252 & 0.11 \\
\hline \multicolumn{7}{|l|}{ Settlement type } \\
\hline Urban & 165,469 & 82.1 & 1,477 & 122 & 1,355 & 0.09 \\
\hline Rural & 36,077 & 17.9 & 137 & 33 & 104 & 0.32 \\
\hline \multicolumn{7}{|c|}{$\begin{array}{l}\text { Share of majority in the } \\
\text { municipality of residence }\end{array}$} \\
\hline Under $30 \%$ & 108,028 & 53.6 & 674 & 33 & 641 & 0.05 \\
\hline $30-69 \%$ & 71,146 & 35.3 & 759 & 61 & 698 & 0.09 \\
\hline $70+\%$ & 22,372 & 11.1 & 181 & 61 & 120 & 0.51 \\
\hline \multicolumn{7}{|l|}{ Educational attainment } \\
\hline Basic & 113,470 & 56.3 & 571 & 72 & 499 & 0.14 \\
\hline Upper secondary & 50,387 & 25.0 & 479 & 37 & 442 & 0.08 \\
\hline Vocational & 33,255 & 16.5 & 483 & 38 & 445 & 0.09 \\
\hline Tertiary & 4,434 & 2.2 & 81 & 8 & 73 & 0.11 \\
\hline \multicolumn{7}{|l|}{ Activity status } \\
\hline Employed & 90,091 & 44.7 & 1,276 & 129 & 1,147 & 0.11 \\
\hline In education & 74,774 & 37.1 & 192 & 15 & 177 & 0.08 \\
\hline Other & 36,681 & 18.2 & 146 & 11 & 135 & 0.08 \\
\hline
\end{tabular}


Puur et al.: The formation of ethnically mixed partnerships in Estonia

Table A-1: (Continued)

c) Majority women

\begin{tabular}{|c|c|c|c|c|c|c|}
\hline \multirow[t]{2}{*}{ Variable } & \multirow{2}{*}{$\begin{array}{l}\text { Exposure time } \\
\text { (number of } \\
\text { person-months) }\end{array}$} & \multirow[t]{2}{*}{$\begin{array}{l}\text { Exposure time } \\
(\%)\end{array}$} & \multicolumn{3}{|c|}{$\begin{array}{l}\text { Number of events } \\
\text { (transition to first partnership) }\end{array}$} & \multirow{2}{*}{$\begin{array}{l}\text { Ratio } \\
\text { (Interethnic to } \\
\text { coethnic) }\end{array}$} \\
\hline & & & All & Interethnic & Coethnic & \\
\hline \multicolumn{7}{|l|}{ Birth cohort } \\
\hline 1924-1929 & 77,075 & 11.7 & 539 & 53 & 486 & 0.11 \\
\hline $1930-1939$ & 142,618 & 21.7 & 1,115 & 85 & 1,030 & 0.08 \\
\hline 1940-1949 & 129,926 & 19.7 & 1,127 & 75 & 1,052 & 0.07 \\
\hline 1950-1959 & 113,891 & 17.3 & 1,092 & 90 & 1,002 & 0.09 \\
\hline 1960-1969 & 109,486 & 16.6 & 1,088 & 63 & 1,025 & 0.06 \\
\hline 1970-1979 & 70,291 & 10.7 & 728 & 36 & 692 & 0.05 \\
\hline $1980-1983$ & 15,087 & 2.3 & 144 & 10 & 134 & 0.07 \\
\hline \multicolumn{7}{|l|}{ Mixed parentage } \\
\hline No & 615,253 & 93.5 & 5,396 & 295 & 5,101 & 0.06 \\
\hline Yes & 43,121 & 6.6 & 437 & 117 & 320 & 0.37 \\
\hline \multicolumn{7}{|c|}{$\begin{array}{l}\text { Minority language at parental } \\
\text { home }\end{array}$} \\
\hline No & 325,540 & 49.4 & 2,846 & 147 & 2,699 & 0.05 \\
\hline Yes & 332,834 & 50.6 & 2,987 & 265 & 2,722 & 0.10 \\
\hline \multicolumn{7}{|c|}{ Minority language at school } \\
\hline No & 322,114 & 48.9 & 2,834 & 146 & 2,688 & 0.05 \\
\hline Yes & 15,020 & 2.3 & 130 & 59 & 71 & 0.83 \\
\hline \multicolumn{7}{|l|}{ Settlement type } \\
\hline Urban & 253,832 & 38.6 & 2,131 & 135 & 1,996 & 0.07 \\
\hline Rural & 404,542 & 61.4 & 3,702 & 277 & 3,425 & 0.08 \\
\hline \multicolumn{7}{|c|}{$\begin{array}{l}\text { Share of majority in the } \\
\text { municipality of residence }\end{array}$} \\
\hline Under $30 \%$ & 22,436 & 3.4 & 170 & 63 & 107 & 0.59 \\
\hline $30-69 \%$ & 170,013 & 25.8 & 1,670 & 144 & 1,526 & 0.09 \\
\hline $70+\%$ & 465,925 & 70.8 & 3,993 & 205 & 3,788 & 0.05 \\
\hline \multicolumn{7}{|l|}{ Educational attainment } \\
\hline Basic & 382,214 & 58.1 & 2,207 & 187 & 2,020 & 0.09 \\
\hline Upper secondary & 150,446 & 22.9 & 1,820 & 112 & 1,708 & 0.07 \\
\hline Vocational & 89,899 & 13.7 & 1,405 & 83 & 1,322 & 0.06 \\
\hline Tertiary & 35,815 & 5.4 & 401 & 30 & 371 & 0.08 \\
\hline \multicolumn{7}{|l|}{ Activity status } \\
\hline Employed & 307,461 & 46.7 & 1,312 & 91 & 1,221 & 0.07 \\
\hline In education & 32,925 & 5.0 & 398 & 21 & 377 & 0.06 \\
\hline Other & 317,988 & 48.3 & 4,123 & 300 & 3,823 & 0.08 \\
\hline
\end{tabular}


Table A-1: (Continued)

d) Majority men

\begin{tabular}{|c|c|c|c|c|c|c|}
\hline \multirow[t]{2}{*}{ Variable } & \multirow[t]{2}{*}{$\begin{array}{l}\text { Exposure time } \\
\text { (number of } \\
\text { person-months) }\end{array}$} & \multirow[t]{2}{*}{$\begin{array}{l}\text { Exposure time } \\
(\%)\end{array}$} & \multicolumn{3}{|c|}{$\begin{array}{l}\text { Number of events } \\
\text { (transition to first partnership) }\end{array}$} & \multirow[t]{2}{*}{$\begin{array}{l}\text { Ratio } \\
\text { (Interethnic to } \\
\text { coethnic) }\end{array}$} \\
\hline & & & All & Interethnic & Coethnic & \\
\hline \multicolumn{7}{|l|}{ Birth cohort } \\
\hline 1924-1929 & 32,161 & 7.5 & 210 & 18 & 192 & 0.09 \\
\hline 1930-1939 & 83,131 & 19.3 & 543 & 49 & 494 & 0.10 \\
\hline 1940-1949 & 85,918 & 19.9 & 624 & 47 & 577 & 0.08 \\
\hline $1950-1959$ & 78,455 & 18.2 & 627 & 53 & 574 & 0.09 \\
\hline 1960-1969 & 77,216 & 17.9 & 626 & 35 & 591 & 0.06 \\
\hline $1970-1979$ & 59,320 & 13.8 & 400 & 25 & 375 & 0.07 \\
\hline $1980-1983$ & 14,490 & 3.4 & 67 & 8 & 59 & 0.14 \\
\hline \multicolumn{7}{|l|}{ Mixed parentage } \\
\hline No & 401,922 & 93.3 & 2,877 & 178 & 2,699 & 0.07 \\
\hline Yes & 28,769 & 6.7 & 220 & 57 & 163 & 0.35 \\
\hline \multicolumn{7}{|c|}{$\begin{array}{l}\text { Minority language at parental } \\
\text { home }\end{array}$} \\
\hline No & 408,990 & 95.0 & 2,933 & 173 & 2,760 & 0.06 \\
\hline Yes & 21,701 & 5.0 & 164 & 62 & 102 & 0.61 \\
\hline \multicolumn{7}{|c|}{ Minority language at school } \\
\hline No & 216,841 & 50.3 & 1,528 & 92 & 1,436 & 0.06 \\
\hline Yes & 14,808 & 3.4 & 122 & 41 & 81 & 0.51 \\
\hline \multicolumn{7}{|l|}{ Settlement type } \\
\hline Urban & 243,634 & 56.6 & 1,961 & 164 & 1,797 & 0.09 \\
\hline Rural & 187,057 & 43.4 & 1,136 & 71 & 1,065 & 0.07 \\
\hline \multicolumn{7}{|c|}{$\begin{array}{l}\text { Share of majority in the } \\
\text { municipality of residence }\end{array}$} \\
\hline Under $30 \%$ & 56,778 & 13.2 & 249 & 66 & 183 & 0.36 \\
\hline $30-69 \%$ & 99,539 & 23.1 & 891 & 85 & 806 & 0.11 \\
\hline $70+\%$ & 274,374 & 63.7 & 1,957 & 84 & 1,873 & 0.04 \\
\hline \multicolumn{7}{|l|}{ Educational attainment } \\
\hline Basic & 281,909 & 65.5 & 1,399 & 108 & 1,291 & 0.08 \\
\hline Upper secondary & 83,298 & 19.3 & 798 & 53 & 745 & 0.07 \\
\hline Vocational & 54,147 & 12.6 & 695 & 61 & 634 & 0.10 \\
\hline Tertiary & 11,337 & 2.6 & 205 & 13 & 192 & 0.07 \\
\hline \multicolumn{7}{|l|}{ Activity status } \\
\hline Employed & 200,066 & 46.5 & 2,412 & 188 & 2,224 & 0.08 \\
\hline In education & 156,718 & 36.4 & 427 & 22 & 405 & 0.05 \\
\hline Other & 73,907 & 17.2 & 258 & 25 & 233 & 0.11 \\
\hline
\end{tabular}

Note: For majority population, information on school language is available only from the Estonian GGS.

Source: Estonian FFS and GGS, authors' calculations. 
Puur et al:: The formation of ethnically mixed partnerships in Estonia

Table A-2: Hazard ratios for the transition to a coethnic first partnership, from proportional hazards models, Estonia, minority population, birth cohorts 1924-1983

\begin{tabular}{|c|c|c|c|c|c|c|c|c|c|c|}
\hline \multirow{2}{*}{ Variable } & \multicolumn{5}{|c|}{ a) Women } & \multicolumn{5}{|l|}{ b) Men } \\
\hline & M1 & M2a & M2b & M3 & M4 & M1 & M2a & M2b & M3 & M4 \\
\hline \multicolumn{11}{|l|}{ Migrant generation/status } \\
\hline Third generation/native & 0.95 & 0.98 & 1.07 & 1.05 & 1.04 & 0.86 & 0.89 & 0.94 & 0.97 & 0.98 \\
\hline Second generation & 0.95 & 0.96 & 1.00 & 0.95 & 0.94 & 0.96 & 0.96 & 0.98 & 0.93 & 0.95 \\
\hline First generation & 1 & 1 & 1 & 1 & 1 & 1 & 1 & 1 & 1 & 1 \\
\hline \multicolumn{11}{|l|}{ Birth cohort } \\
\hline 1924-1929 & $0.71^{\star \star *}$ & $0.71^{* * *}$ & $0.70^{* * *}$ & $0.76 * * *$ & 0.76 *** & $0.73^{* * *}$ & $0.73^{* * *}$ & $0.72^{* \star *}$ & $0.81 *$ & 0.95 \\
\hline $1930-1939$ & $0.77^{* \star *}$ & $0.76^{* * *}$ & $0.77^{* \star *}$ & $0.79^{* \star *}$ & 0.78 *** & $0.75^{* * *}$ & $0.75^{* * *}$ & 0.75 *** & $0.77^{\star \star *}$ & 0.82 ** \\
\hline $1940-1949$ & $0.88^{* *}$ & $0.88^{* *}$ & $0.88^{\star *}$ & $0.88^{* *}$ & $0.87^{* *}$ & $0.82^{* *}$ & $0.82^{* *}$ & $0.82^{* \star}$ & $0.82 * *$ & $0.85^{* *}$ \\
\hline 1950-1959 & 1 & 1 & 1 & 1 & 1 & 1 & 1 & 1 & 1 & 1 \\
\hline $1960-1969$ & 1.26 *** & $1.26^{* * *}$ & 1.24 *** & 1.23 *** & 1.22 *** & 0.96 & 0.97 & 0.95 & 0.93 & 0.93 \\
\hline 1970-1979 & 1.05 & 1.04 & 1.06 & 1.04 & 1.04 & $0.60^{* * *}$ & $0.60^{* * *}$ & $0.61^{* * *}$ & $0.57^{* * *}$ & $0.55^{* * *}$ \\
\hline $1980-1983$ & $0.68^{* * *}$ & $0.68^{* * *}$ & $0.72^{* *}$ & $0.70^{* *}$ & 0.84 & 0.62 ** & $0.62^{* *}$ & 0.68 * & 0.64 ** & $0.63^{\text {** }}$ \\
\hline \multicolumn{11}{|l|}{ Mixed parentage } \\
\hline No & & 1 & 1 & 1 & 1 & & 1 & 1 & 1 & 1 \\
\hline Yes & & 0.88 & 1.03 & 1.01 & 1.05 & & 0.83 & 0.98 & 1.00 & 0.98 \\
\hline \multicolumn{11}{|c|}{$\begin{array}{l}\text { Majority language at parental } \\
\text { home }\end{array}$} \\
\hline No & & & 1 & 1 & 1 & & & 1 & 1 & 1 \\
\hline Yes & & & 0.58 *** & 0.62 *** & $0.60^{* \star *}$ & & & 0.69 ** & 0.73 * & 0.78 \\
\hline \multicolumn{11}{|l|}{ Majority language at school } \\
\hline No & & & 1 & 1 & 1 & & & 1 & 1 & 1 \\
\hline Yes & & & $0.74^{* *}$ & 0.78 * & 0.87 & & & 0.34 *** & $0.37^{* * *}$ & $0.40^{* *}$ \\
\hline \multicolumn{11}{|l|}{ Minority group size } \\
\hline Size $(\ln )$ & & & & 1.02 & 1.02 & & & & 0.97 & $0.97^{*}$ \\
\hline \multicolumn{11}{|l|}{ Settlement type } \\
\hline Urban & & & & 1 & 1 & & & & 1 & 1 \\
\hline Rural & & & & $0.83^{* * *}$ & $0.79 * * *$ & & & & $0.55^{* * *}$ & $0.57^{* * *}$ \\
\hline \multicolumn{11}{|l|}{$\begin{array}{l}\text { Share of majority in the } \\
\text { municipality of residence }\end{array}$} \\
\hline Under $30 \%$ & & & & 1 & 1 & & & & 1 & 1 \\
\hline $30-69 \%$ & & & & 1.12 ** & 1.07 * & & & & $1.26^{* * *}$ & 1.70 \\
\hline $70+\%$ & & & & 0.89 * & 0.89 * & & & & 0.88 & $0.77^{\text {** }}$ \\
\hline \multicolumn{11}{|l|}{ Educational attainment } \\
\hline Basic & & & & & $0.85^{* * *}$ & & & & & $0.87^{*}$ \\
\hline Upper secondary & & & & & & & & & & \\
\hline Vocational & & & & & $1.11^{*}$ & & & & & 1.06 \\
\hline Tertiary & & & & & 0.91 & & & & & 0.94 \\
\hline \multicolumn{11}{|l|}{ Activity status } \\
\hline Employed & & & & & 1 & & & & & 1 \\
\hline In education & & & & & $0.45^{\star \star}$ & & & & & $0.51^{\star \star \star}$ \\
\hline Other & & & & & 1.11 & & & & & $0.33^{* * *}$ \\
\hline
\end{tabular}

Note: ${ }^{* *} p<0.01,{ }^{* *} p<0.05,{ }^{*} p<0.1$. Time at risk starts at age 15 ; censoring occurs at interview date, the respondent's $45^{\text {th }}$ birthday, or at entry into minority-majority partnership.

Source: Estonian FFS and GGS, authors' calculations. 
Table A-3: Hazard ratios for the transition to a coethnic first partnership, from proportional hazards models, Estonia, majority population, birth cohorts 1924-1983

\begin{tabular}{|c|c|c|c|c|c|c|c|c|c|c|}
\hline \multirow{2}{*}{ Variable } & \multicolumn{5}{|c|}{ a) Women } & \multicolumn{5}{|l|}{ b) Men } \\
\hline & M1 & M2a & M2b & M3 & M4 & M1 & M2a & M2b & M3 & M4 \\
\hline \multicolumn{11}{|l|}{ Migrant generation/status } \\
\hline Third generation/native & 1 & 1 & 1 & 1 & 1 & 1 & 1 & 1 & 1 & 1 \\
\hline Second generation & 0.64 *** & $0.65^{* * *}$ & $0.68 * * *$ & $0.70^{* * *}$ & $0.70^{* * *}$ & 0.91 & 0.97 & 1.02 & 0.98 & 0.95 \\
\hline First generation & 0.82 ** & $0.82^{* *}$ & 0.89 & 0.93 & 0.94 & 0.80 * & 0.82 * & 0.89 & 0.97 & 0.95 \\
\hline \multicolumn{11}{|l|}{ Birth cohort } \\
\hline $1924-1929$ & 0.66 *** & $0.66^{* * *}$ & $0.65^{* * *}$ & $0.65^{* * *}$ & $0.69 * * *$ & $0.69 * * *$ & $0.69 * * *$ & $0.69 * * *$ & $0.70^{* \star *}$ & $0.73^{* * *}$ \\
\hline $1930-1939$ & $0.75^{\star \star \star}$ & $0.75^{\star \star \star}$ & $0.75^{* \star *}$ & $0.74^{* \star \star}$ & $0.74 * * \star$ & $0.71^{* \star *}$ & $0.71^{\star \star \star}$ & $0.71^{\star * \star}$ & $0.71^{\star \star \star}$ & $0.71^{* * *}$ \\
\hline $1940-1949$ & $0.88^{\star \star \star}$ & $0.88^{\star \star *}$ & $0.88^{* \star *}$ & $0.87^{\star \star \star}$ & $0.88^{* * *}$ & $0.85^{* \star *}$ & $0.85^{\star \star *}$ & $0.85^{* \star *}$ & $0.87^{* *}$ & 0.86 ** \\
\hline $1950-1959$ & 1 & 1 & 1 & 1 & 1 & 1 & 1 & 1 & 1 & 1 \\
\hline $1960-1969$ & 1.08 * & 1.08 * & 1.08 * & 1.09 * & 1.08 * & 1.06 & 1.06 & 1.06 & 1.07 & 1.07 \\
\hline $1970-1979$ & $1.14^{\star \star *}$ & $1.14^{* \star *}$ & $1.18^{* * *}$ & $1.20^{* * *}$ & 1.22 *** & $0.87^{* *}$ & $0.87^{\text {** }}$ & $0.89^{*}$ & $0.80^{* * *}$ & $0.79^{* * *}$ \\
\hline $1980-1983$ & 1.16 & 1.16 & 1.22 ** & 1.24 ** & $1.48^{* \star \star}$ & 0.85 & 0.85 & 0.87 & $0.74 * *$ & 0.82 \\
\hline \multicolumn{11}{|l|}{ Mixed parentage } \\
\hline No & & 1 & 1 & 1 & 1 & & 1 & 1 & 1 & 1 \\
\hline Yes & & 0.97 & 1.00 & 1.00 & 0.98 & & 0.88 & 0.98 & 0.96 & 0.97 \\
\hline \multicolumn{11}{|c|}{$\begin{array}{l}\text { Minority language at parental } \\
\text { home }\end{array}$} \\
\hline No & & & 1 & 1 & 1 & & & 1 & 1 & 1 \\
\hline Yes & & & 0.90 & 0.92 & 0.92 & & & $0.75^{* *}$ & $0.80^{*}$ & $0.75^{* *}$ \\
\hline \multicolumn{11}{|l|}{ Minority language at school } \\
\hline No & & & 1 & 1 & 1 & & & 1 & 1 & 1 \\
\hline Yes & & & $0.66^{* \star \star}$ & 0.72 ** & $0.70^{\star \star \star}$ & & & 0.99 & 1.03 & 0.97 \\
\hline \multicolumn{11}{|l|}{ Settlement type } \\
\hline Urban & & & & 1 & 1 & & & & 1 & 1 \\
\hline Rural & & & & $1.15^{* * *}$ & $1.08^{\text {** }}$ & & & & $0.79^{* \star *}$ & $0.77^{* * *}$ \\
\hline \multicolumn{11}{|l|}{$\begin{array}{l}\text { Share of majority in the } \\
\text { municipality of residence }\end{array}$} \\
\hline Under $30 \%$ & & & & 1 & 1 & & & & 1 & 1 \\
\hline $30-69 \%$ & & & & $1.59 * * *$ & $1.61^{\star \star \star}$ & & & & $2.73^{* \star \star}$ & $1.70^{* \star \star}$ \\
\hline $70+\%$ & & & & $1.55^{* * *}$ & $1.58^{\star \star *}$ & & & & $2.83^{* * *}$ & $1.74^{* * *}$ \\
\hline \multicolumn{11}{|l|}{ Educational attainment } \\
\hline Basic & & & & & $0.84^{\star \star \star}$ & & & & & 0.95 \\
\hline Upper secondary & & & & & 1 & & & & & 1 \\
\hline Vocational & & & & & 1.06 & & & & & $1.15^{\text {***}}$ \\
\hline Tertiary & & & & & 1.00 & & & & & $1.25^{* * *}$ \\
\hline \multicolumn{11}{|l|}{ Activity status } \\
\hline Employed & & & & & 1 & & & & & 1 \\
\hline In education & & & & & $0.46^{* * *}$ & & & & & 0.56 *** \\
\hline Other & & & & & $1.18^{\star \star *}$ & & & & & $0.39^{* * *}$ \\
\hline
\end{tabular}

Note: ${ }^{* \star} p<0.01,{ }^{* *} p<0.05,{ }^{*} p<0.1$. Time at risk starts at age 15 ; censoring occurs at interview date, the respondent's $45^{\text {th }}$ birthday, or at entry into majority-minority partnership.

Source: Estonian FFS and GGS, authors' calculations. 
Puur et al.: The formation of ethnically mixed partnerships in Estonia 